\title{
Review
}

\section{Maize and Sorghum as Raw Materials for Brewing, a Review}

\author{
Adriana Dabija, Marius Eduard Ciocan, Ancuta Chetrariu and Georgiana Gabriela Codină *(D)
}

check for updates

Citation: Dabija, A.; Ciocan, M.E.; Chetrariu, A.; Codină, G.G. Maize and Sorghum as Raw Materials for Brewing, a Review. Appl. Sci. 2021, 11, 3139. https://doi.org/10.3390/ app11073139

Academic Editor:

Wojciech Kolanowski

Received: 13 March 2021

Accepted: 29 March 2021

Published: 1 April 2021

Publisher's Note: MDPI stays neutral with regard to jurisdictional claims in published maps and institutional affiliations.

Copyright: (c) 2021 by the authors. Licensee MDPI, Basel, Switzerland. This article is an open access article distributed under the terms and conditions of the Creative Commons Attribution (CC BY) license (https:// creativecommons.org/licenses/by/ $4.0 /)$.
Faculty of Food Engineering, Stefan cel Mare University of Suceava, 720229 Suceava, Romania; adriana.dabija@fia.usv.ro (A.D.); marius_ec@yahoo.com (M.E.C.); ancuta.chetrariu@fia.usv.ro (A.C.)

* Correspondence: codina@fia.usv.ro; Tel.: +40-745-460-727

\begin{abstract}
Brewing is among the oldest biotechnological processes, in which barley malt and-to a lesser extent-wheat malt are used as conventional raw materials. Worldwide, $85-90 \%$ of beer production is now produced with adjuvants, with wide variations on different continents. This review proposes the use of two other cereals as raw materials in the manufacture of beer, corn and sorghum, highlighting the advantages it recommends in this regard and the disadvantages, so that they are removed in technological practice. The use of these cereals as adjuvants in brewing has been known for a long time. Recently, research has intensified regarding the use of these cereals (including in the malted form) to obtain new assortments of beer from $100 \%$ corn malt or $100 \%$ sorghum malt. There is also great interest in obtaining gluten-free beer assortments, new nonalcoholic or low-alcohol beer assortments, and beers with an increased shelf life, by complying with current food safety regulations, under which maize and sorghum can be used in manufacturing recipes.
\end{abstract}

Keywords: craft beer; gluten-free beer; functional beer; adjuvants; malted cereals

\section{Introduction Cross-Reference}

Brewing is a food process that began in the Middle East 10,000 years ago [1]. Today, at almost 200 billion liters a year, beer is one of the most commonly consumed low-alcohol beverages in the world-and, in terms of volume, after water and tea, the third most prevalent beverage in general [2-6]. The largest manufacturer of beer in the world is China, followed by the USA and Brazil. In Europe, Germany has the highest rates of beer consumption and production [7].

Dating back to antiquity, people have exploited the grains in their vicinity to develop fermented drinks [8]. Over the past hundred years, advancements in brewing have led manufacturers to use other types of cereals, in addition to barley malt or wheat malt. In any industry, innovation is the key to remaining competitive, and the beer industry is no exception. Consumers are always searching for new products on the marketplace-a novel brand, an original taste, eye-catching packaging, innovative technology, health benefits, quality improvements, etc. [9-11]. Barley is the most used cereal for brewing; however, unconventional malted grains have been used successfully. For instance: rice is used in Asia, maize is used in America, and millet and sorghum are used in Africa [12-14]. This process of replacing barley malt in beer production is increasing, and several factors shown in Figure 1 have contributed to this.

Because barley is used in such large quantities by all brewers, no matter their size, manufacturers often adopt various cost-cutting strategies. These can include the partial replacement of barley malt with adjuvants, considered supplementary sources of carbohydrates. The first adjuvants used in brewing were used to reduce the costs of obtaining the finished product [15]. For this reason, local raw materials-which may be available at lower costs and in higher quantities — can be used, provided they are in compliance with applicable legislation. Barley and maize are the most commonly used adjuvants in Europe as partial substitutes for malt [15-17]. 
Adjuvants are widely used in the beer industry (in variable proportions ranging from $10-50 \%$ ) to provide additional sources of fermentable yeast carbohydrates, to improve foam stability, to change the color of beer, or to adjust the flavor of the finished product [18]. The literature states that $85-90 \%$ of world beer production is now produced with adjuvants, with wide variations on different continents. Between $10 \%$ and $30 \%$ of malt is substituted by unmalted materials in European countries; $40-50 \%$ or more is substituted in the United States and Australia, and in Africa the substitution is between 50 and 75\% [17].

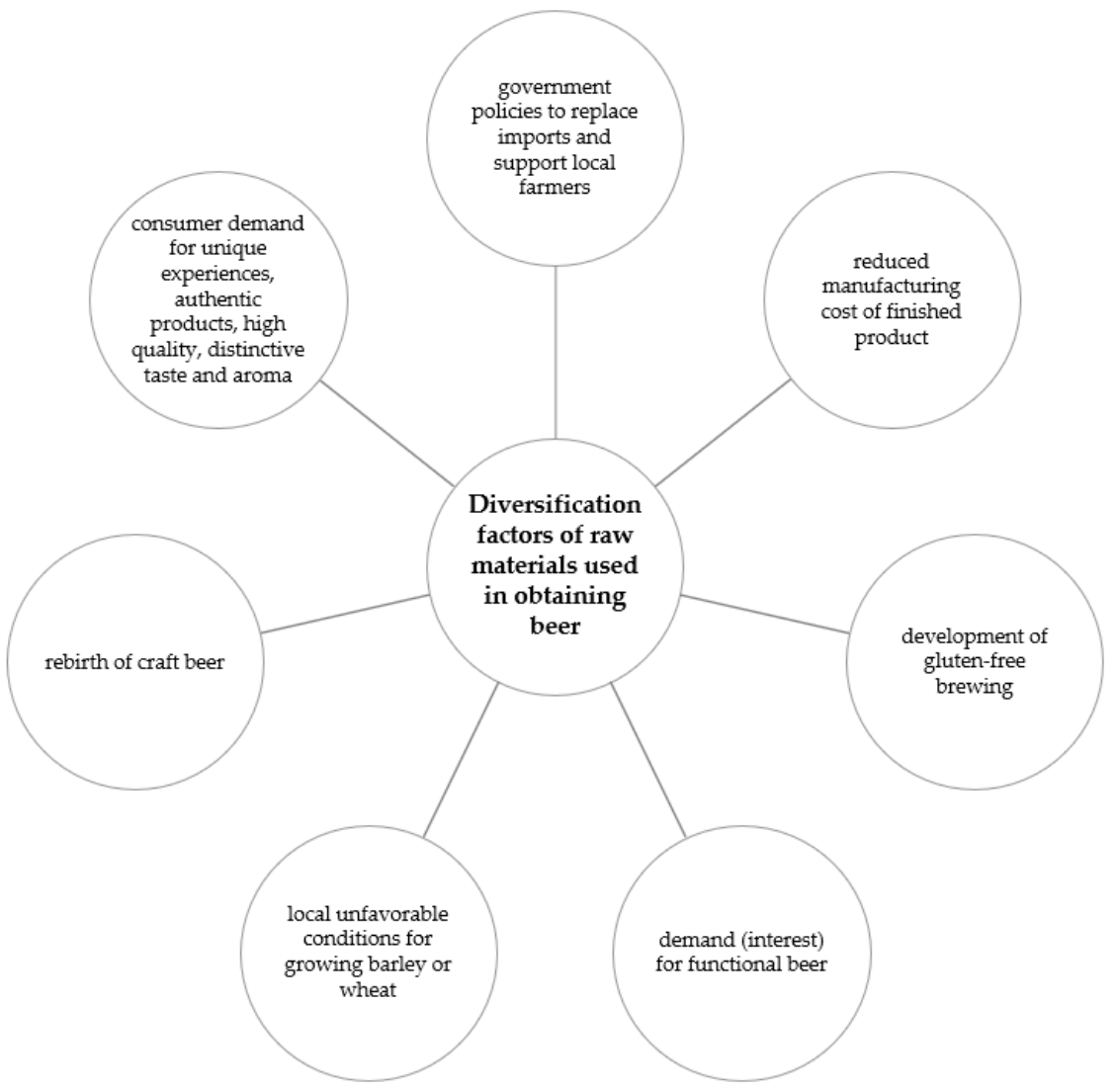

Figure 1. Diversification factors of raw materials for obtaining beer.

Beer adjuvants are ingredients-not including malted barley-that bring supplementary sources of protein and carbohydrates into the wort. Various cereals-e.g., wheat, barley, sorghum, corn, rice, and oats-are frequently used in various forms (whole grains, semolina, flakes, boiled, extruded, roasted/micronized, flour/starch, syrup, etc.) to obtain different beers [19]. For example, the use of maize as an adjuvant in the manufacture of a $30 \%$ beer assortment has led to an $8 \%$ reduction in total production costs [20]. In the Netherlands, Belgium, Luxembourg, and France, the production of beer with up to $40 \%$ unmalted cereals is permitted by law and has been put into practice. Contrastingly, beer production using higher concentrations of adjuvants $(>40 \%)$ is often prohibited or impracticable. Replacing barley malt with adjuvants in beer manufacturing can potentially reduce the total cost of raw materials and obtain a distinctive beer taste or aroma [21]. Currently, the most common adjuvant of beer is rice, but as the demand for this cereal has risen severely, the quest for more adjuvants to substitute rice is ongoing [22].

Some adjuvants could feature compounds that may have beneficial effects on people's health-e.g., vitamins, minerals, and phenolic compounds such as phytoestrogens [23].

On the other hand, in recent decades, the beer industry has faced a phenomenon: the rebirth of craft beer, whose origins date back to the 1970s in the United States. The growing popularity of this beer submarket has benefited from innovation, creativity and authenticity. Craft beers are characterized as giving pleasure, joy, a feeling of identity, social 
recognition, self-satisfaction and sustainability. When brewing craft beer, the potential for improvement in unconventional starch ingredients is exploited to obtain a note of uniqueness, often by adding local fruits, herbs, spices and vegetables. These tactics are at the heart of local gastronomic traditions. Last but not least, the craft beer industry adds to the body of technical brewing knowledge by reinterpreting traditional styles [24-26].

Great creative innovations are possible when formulating beers. The options are plentiful; brewers only need to meet customer requirements and build a market founded on their needs. While craft beer producers have experimented to obtain new assortments, functional beer producers could similarly obtain high value products. An original product must be described in clear terms, including: its health benefits, the concentration of functional ingredients added, as well as its organoleptic profile, quality, safety and shelf life [4].

Another increasing production segment in the brewing industry is the manufacture of gluten-free beer. As stated by Codex Alimentarius and EU Regulation 41/2009 for glutenfree foods, gluten-free or non-gluten beer can be defined as beer with less than $20 \mathrm{mg} / \mathrm{kg}$ of gluten $[27,28]$. The manufacturing and marketing of gluten-free beers $(<20 \mathrm{mg} / \mathrm{L})$ and beers with extremely low gluten content $(<100 \mathrm{mg} / \mathrm{L})$ is still in its infancy, and the European market value is already estimated at several billion Euros per year. The majority of gluten-free beers need to use at least a fraction of malt obtained from pseudocereals and cereals that do not contain gluten or its precursors, including quinoa, amaranth, sorghum, buckwheat, maize, and rice [29]. Currently, research on the production of non-gluten beer from buckwheat malt, sorghum malt, quinoa malt and amaranth malt is the most developed. These types of malt contain high starch and moderate protein levels. Techniques for producing cereal beers other than barley and wheat are not yet well developed [30].

Beer producers have considered that the removal of gluten from beer malt is an expensive and complex process, which raises the price of the end product. On the other hand, in the USA, the Food and Drug Administration (FDA) does not allow beers made from gluten-containing raw materials to be considered non-gluten products [29].

The primary driver for research is the desire to expand efficient means of producing gluten-free malt beer. A crucial aspect in non-gluten beers is their taste; beers made from pseudocereals differ significantly from conventional beers in flavor profile. Techniques for the manufacture of non-gluten beers from other ingredients are therefore constantly being improved so that they can be marketed as beer products that comply with the regulations in force [31].

Unfavorable growing conditions for barley or wheat in some parts of the world (including those attributable to climate change) have led beer producers to the use of more versatile local raw materials to replace barley and wheat in conventional recipes. Extreme weather events can lead to substantial declines in global barley production, with a potential loss of $17 \%$ in the most severe conditions. This declining global barley supply could lead to higher beer prices, with a potential prince increase of 193\% by 2099 [32]. This has led to the use of indigenous raw materials - often supported by government import substitution policies-and provided support to local farmers [33].

Consumers have become more and more aware that beer is a multifaceted product that has the potential to suit several settings and conditions. This may be why beer drinkers are especially inclined to experiment with authentic, high-quality products with distinctive tastes and aromas [25,33].

Maize and sorghum are among the most explored crops on earth, with multiple uses. These crops are grown in all agro-ecological areas of the world [34]. In this review, we address aspects of these two grains and how they might serve as possible substitutes for barley malt in brewing. Although obtaining an assortment of beer from cereals other than barley is simple, managing the efficiency of the economic process and creating a product acceptable to consumers presents a long-term research challenge. 


\section{Maize and Sorghum: Raw Materials for Brewing}

In the process of obtaining beer, barley is the most common malted raw material in current use [35]. The advantages of using this cereal for brewing are well known. Barley malt production is among the oldest and most complex examples of applied biotechnology [36]. This review details two other cereals (maize and sorghum) which are currently used in brewing, emphasizing the characteristics that recommend them in this regard.

\subsection{Overview}

Maize is widely grown in over 166 countries, including all agro-ecological areas (arid, semi-arid, temperate and tropical) of the world, e.g., the tropics of Central America and Mexico, from whence it originates [34,37,38]. Main maize-producing countries include: United States, China, Brazil, Argentina, India, France, and Indonesia [39].

Maize (Zea mays L.) is a significant annual cereal crop belonging to the Poaceae family. Zea comes from ancient Greece (meaning "life support") and mays is a Latin word that means "giver of life". Maize is among the top three crops worldwide, after rice and wheat [40]. It is also known as the miracle crop and the queen of cereals, due to its high production potential [38]. Internationally, maize is grown on 184 million hectares, with 1016 million tons produced annually [41].

In addition to its use as human food and animal feed, maize is a source for a huge number of industrial products. Corn is grown in a multitude of varieties (e.g., white grain, the more common yellow grain, sweet corn, baby corn, waxy corn, popcorn, high amylase corn, flour corn, flint corn, high oil corn, dent corn, amylomaize, and quality protein maize) which appropriately meet nutritional demands. Corn varieties may differ in color, including yellow, white, red, and purple. Interest in the research and use of pigmented maize - which is full of anthocyanins, carotenoids and phenolic substances with antioxidant and bioactive characteristics-has increased due to its benefits on human health $[38,39]$. Maize has not been found in the wild in any part of the world. It survives only through human care [34].

Sorghum (Sorghum vulgare) originates from central Africa, and has reached Asia (including India). It belongs, like barley and maize, to the Poaceae family. Sorghum is closely related to corn in genomic organization, plant shape, developmental physiology, and even in its applications. Sorghum is the fifth most important cereal harvest in the world after corn, rice, wheat and barley, and serves as a major food grain for over 750 million people residing in the semi-arid tropical regions of Africa (Burkina Faso, Nigeria, Ethiopia, Sudan), Asia (China, India), and areas of Central and South America [21,30,42]. According to the FAOSTAT's (Statistics Division of Food Agriculture Organization of the United Nation) 2017 statistical data, Africa is the largest contributor to worldwide sorghum production, with approximately 29.7 million tons out of a total of 57 million tons [43,44].

Compared to other cereal crops, sorghum is more drought-tolerant; it is also called the camel plant. Therefore, this cereal is a vital staple food in many semi-arid areas of the developing world. In western countries, it is mainly consumed as animal feed [21]. Sorghum requires less fertilizer than corn. Sorghum is highly efficient in its use of heat from solar radiation, and uses water more efficiently than corn [36]. Sorghum is among the most versatile food crops in Africa, which has a rate of human consumption comprising about $40 \%$ of total world production [30]. During drought, sorghum rolls its leaves to reduce water loss due to perspiration. If the drought continues, it becomes latent rather than dying. The leaves are protected by waxy cuticles to reduce evaporation [42]. With continuing increases in the world's population, declining water supplies and the consequences of climate change, sorghum could be vital for human use and will be a significant crop in the future due to its drought resistance [43].

Usually, the color of sorghum grains varies from red, black and brown to coffeecolored, yellow and white. The variety of colors or pigments is due to the different quantity of polyphenols in the grain, which are usually located in the pericarp. To date, there are more than 10,000 types of sorghum, with more being generated through incessant plant 
growth research to choose desired properties. The majority of sorghum types vary in size, structure, pigmentation, texture, hardness and biochemical properties [45].

Sorghum also grows wild, especially on its continent of origin (Africa) [46].

\subsection{Chemical Structure and Composition}

Barley, maize and sorghum are part of the Poaceae family, all of which are monocotyledonous herbaceous plants with fasciculate roots and stems-formed by nodes and internodes—with spike-shaped inflorescence (Figure 2) [47].

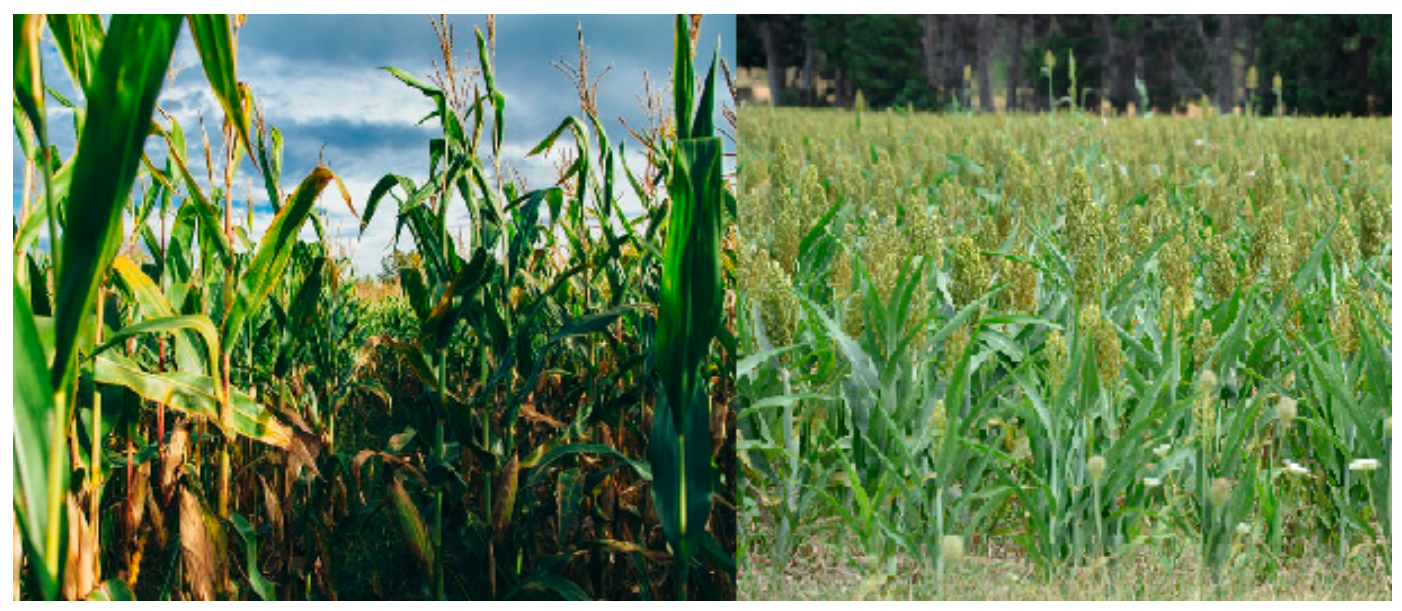

Figure 2. Plants of maize and sorghum.

The grains are caryopses; barley grains have a straw-like, sticky coating, which protects the germs during the malting process, while maize and sorghum are bare grains, devoid of this coating. The average dimensions of barley grains are generally between $8-12 \mathrm{~mm}$ long, 3-5 mm wide and 2-4.5 $\mathrm{mm}$ thick. Depending on the variety and cultivation conditions, the weight of 1000 grains can vary between $37-45 \mathrm{~g}$ [48]. Barley grains are composed of endosperms (80-90\%), embryos (2-5\%), and shells (8-15\%).

The maize grain is $2.5-22 \mathrm{~mm}$ long and 3-8 $\mathrm{mm}$ wide. Depending on the variety and cultivation conditions, the weight of 1000 grains vary greatly (between 30 and $1200 \mathrm{~g}$ ). Maize grains are constituted of endosperms ( $82-83 \%)$, germs (10-11\%), pericarps (5-6\%), and peaks $(0.8-1.0 \%)$ [49].

Sorghum grains are rounded and sharp with a diameter of 4-8 $\mathrm{mm}$. They vary in size, shape and color depending on the variety of sorghum. The weight of 1000 grains varies between 20 and $60 \mathrm{~g}$. These grains are composed of endosperms (80-84.6\%), embryos (7.8-12.1\%), and shells (7.3-9.3\%) [50].

For the beer industry, the chemical composition of raw materials is particularly important. Table 1 summarizes the physicochemical characteristics of the maize, sorghum, and barley.

The composition of cereals (shown in Table 1) varies according to seed maturity, date of harvest, variety/species, soil and climatic conditions, crop management, storage, and drying conditions applied after harvest.

Starch is the main component of cereals, and is the main substance that is later converted to fermentable carbohydrates in beer wort. Therefore, one can determine the brewing qualities of a raw material by examining the starch content. This is important for the alcohol industry. The highest amount of starch is found in maize $(62-80 \%)$, followed by sorghum $(55.60-76.20 \%)$, and then barley (52.10-69.08\%). The protein content varies between $8-15.25 \%$ for barley, $5.8-13.7 \%$ for maize, and $4.4-14.86 \%$ for sorghum. The fat content is $1.09-3 \%$ for barley and $2.2-5.91 \%$ for maize. Sorghum varies greatly, with a lipid content between $1.38-10.54 \%$. 
Table 1. Physicochemical characteristics of maize, sorghum and barley.

\begin{tabular}{|c|c|c|c|c|c|c|c|}
\hline \multirow{2}{*}{ Grain } & \multicolumn{5}{|c|}{ Characteristic, [\% DM *] } & \multirow{2}{*}{ Moisture [\%] } & \multirow{2}{*}{ References } \\
\hline & Starch & Proteins & Lipid & Fiber & Ash & & \\
\hline \multirow{8}{*}{ Barley } & 60 & $8-13$ & - & $2-10$ & - & - & [51] \\
\hline & $65-68$ & $10-17$ & $2-3$ & $11-24$ & $1.5-2.5$ & - & [52] \\
\hline & $63-65$ & $8-11$ & $2-3$ & - & 2 & $14-15$ & [19] \\
\hline & $62-64$ & $11.09-14.68$ & $2.01-2.35$ & $18.7-19.5$ & - & - & [53] \\
\hline & $66.97-69.08$ & $10.35-12.38$ & $1.58-1.71$ & $3.57-5.12$ & $1.94-2.39$ & - & [54] \\
\hline & $59.50-60.98$ & $14.53-15.25$ & $1.82-1.87$ & $2.85-3.25$ & $2.42-2.52$ & - & [55] \\
\hline & $65.45-69.08$ & $10.37-11.93$ & $1.09-2.00$ & $3.07-5.10$ & $1.94-2.40$ & - & [56] \\
\hline & $52.1-64.4$ & $8.7-13.1$ & $2.2-3.5$ & $13.6-23.8$ & $2.0-2.6$ & & [57] \\
\hline \multirow{8}{*}{ Maize } & 71.88 & 8.84 & 4.57 & 2.15 & 2.33 & 10.23 & [40] \\
\hline & $74.4-76.8$ & $8.05-11.03$ & 5.91 & - & - & 15 & [39] \\
\hline & $76-80$ & $9-12$ & $4-5$ & - & 3.87 & 10-14 & [58] \\
\hline & - & $8.92-10$ & - & $1.3-6.26$ & $1.20-2.38$ & - & [41] \\
\hline & 70.99 & 9.21 & 5.10 & 2.21 & 1.05 & 11.44 & [59] \\
\hline & $62-78$ & 10 & 4.4 & - & - & - & [33] \\
\hline & 71.7 & 9.5 & 4.3 & 2.6 & 1.4 & - & [60] \\
\hline & $72-73$ & $5.8-13.7$ & $2.2-5.7$ & $0.8-2.9$ & $1.2-2.9$ & $9.5-12.2$ & [61] \\
\hline \multirow{8}{*}{ Sorghum } & - & 9.4 & 2.8 & - & 2.1 & - & [13] \\
\hline & $61.0-74.8$ & $9.0-13.5$ & $2.8-4.8$ & - & $1.2-1.8$ & $9-12$ & [21] \\
\hline & $55.6-75.2$ & $4.4-21.1$ & $2.1-7.6$ & $1-3.4$ & $1.3-3.3$ & - & [42] \\
\hline & $65.15-75.2$ & $6.23-14.86$ & $1.38-10.54$ & $1.65-7.94$ & $0.90-4.20$ & 1.39-19.02 & [43] \\
\hline & $70.65-76.20$ & $8.90-11.02$ & $2.30-2.80$ & $1.40-2.70$ & $0.92-1.75$ & $8.10-9.99$ & {$[62]$} \\
\hline & - & 12.5 & 3.30 & 1.7 & 1.9 & 9.8 & [63] \\
\hline & 71.95 & 11.36 & 4.70 & 2.76 & 3.17 & 6.07 & [64] \\
\hline & $64.3-73.8$ & 8.19-14.02 & $2.28-4.98$ & $1.41-2.55$ & $1.46-2.32$ & & [65] \\
\hline
\end{tabular}

*DM-dry matter.

According to the chemical composition of maize grains, carbohydrates and proteins are its key components play a significant role in the process of obtaining beer. The major chemical component of the maize kernel is starch, concentrated in the endosperm. The composition of maize starch is genetically controlled. Amylopectin and amylose are the main components of starch. Normal corn usually contains $25-30 \%$ amylose and $70-75 \%$ amylopectin. Nevertheless, maize types with amylose contents as high as $85 \%$ (amylomaize) and as low as 1\% or even less (waxy maize) have been reported. In maize grains, starch can be found in granular forms which vary in size and shape depending on the type of maize. Normal maize starch has a bimodal particle size distribution, with granules $<10 \mu \mathrm{m}$ and $>10 \mu \mathrm{m}$ in relative percentages of $10.2 \%$ and $89.8 \%$, respectively. A cell's walls contain proteins, phenolic acids and nonstarch polysaccharides such as $\beta$-glucan and arabinoxylan [39].

A second component of maize kernels is protein. Maize varieties have different levels of protein content. Waxy corn grains have higher protein content $(11.03 \%)$ than normal corn $(8.05-8.62 \%)$ and flint corn $(8.5-8.7 \%)$. Zein represents about $60 \%$ of the total protein in corn. Zein contains very low lysine and tryptophan percentages. Zein is comprised of $21.4 \%$ glutamine, $19.3 \%$ leucine, $9.0 \%$ proline, $8.3 \%$ alanine, $6.8 \%$ phenylalanine, $6.2 \%$ isoleucine, $5.7 \%$ serine, and $5.1 \%$ tyrosine.

Depending on the type of maize, the grain can contain lipids up to $5.91 \%$. Even though the lipid percentage can be high, the fat content of the endosperm can be relatively low (approximately 1\%). Saturated fatty acids are more abundant in the lipids from the endosperm, compared to the lipids from the germ.

Pigmented maize types are distinct due to their higher quantity of phenolic compounds (flavonoids) especially anthocyanins. The color of these substances is contingent upon the quantity and location of the substituents in the molecule. A prevalence of methoxyls usually creates a red tint, whereas any growth in the amount of hydroxyl groups 
creates tones of blue pigment. The anthocyanins present in blue maize originate from cyanidin and malvidin, while those in red maize originate from malvidin, pelargonidin, and cyanidin [39]. In the structure of cereals, anthocyanins can be found in both the pericarp and the aleuronic layer [8]. Carotenoids with oxygen-containing molecules (xanthophylls) give maize its yellow color. Numerous researchers have emphasized the profile of phenolic acids and anthocyanins and the antioxidant activity of different types of maize; they have indicated antioxidant, anticarcinogenic and antimutagenic capacities [8]. The antioxidant activity of phytochemicals related to maize grains is stated to be $157.68 \mu \mathrm{mol} / \mathrm{g}$ compared to $68.74,43.60$, and $39.76 \mu \mathrm{mol} / \mathrm{g}$ in wheat, oats, and rice grains, respectively [39].

Maize contains vitamins C, E, K, B1, B2, B3, B5, folic acid, selenium, Np-coumaril tryptamine, $\mathrm{N}$-ferulyl tryptamine, and several minerals-the most important being potassium. However, corn may contain antinutritional compounds such as $\alpha$-amylase, trypsin and phytates inhibitors. These compounds can inhibit digestibility, absorption and utilization of nutrients. Microbiological activity during alcoholic fermentation in brewing can help reduce these antinutritional factors and favorably impact the nutritional properties of the finished product [40].

The composition of sorghum grains and their constituent parts is generally similar to maize, except for the lipid content (which is lower). The major component of sorghum is starch; dietary fiber present in the cell wall makes up 75\% of grains. The content of starch-free polysaccharides (NSPs) in sorghum grains suggests their possible ability to lower cholesterol levels and improve bowel function in humans [43]. The total soluble sugar content of sorghum cereals ranges from 0.7 to $4.2 \%$, while reducing sugars range from 0.05 to $0.53 \%$ [30].

As many studies have indicated, sorghum grains are a good source of energy, as well as vitamins, minerals, carbohydrates, polyunsaturated fatty acids (PUFA), and some essential amino acids. Linoleic acid and oleic acid are the main fatty acid components of sorghum lipids. The grains are usually eaten with the testa, which retain most of the nutrients. Sorghum is a good source of minerals; however, the wide spread variety of its mineral composition is generated by environmental settings [42].

Sorghum contains both essential and nonessential amino acids, including alanine (7.34-9.62 g/100 g), aspartic acid (4.83-7.06 g/100 g), glutamic acid (17.5-28.12 g/100 g), leucine (12.02-14.48 g/100 g), phenylalanine (4.03-5.62 g/100 g), proline (6.66-12.34 g/100 g), and valine (4.22-6, 86 g/100 g). It has reduced values for tryptophan and lysine. However, it has bioactive peptides and beneficial protein fractions-e.g., $\alpha$-caffeine, kafirin, protease, amylase and xylanase inhibitors. Sorghum also contains cationic peroxidase, which has anticancer, antiviral, and antioxidant properties, and can lead to decreased cholesterol and reduced risk of hypertension.

Available studies have also shown that sorghum contains a number of minerals and vitamins, which are part of the vital nutrients that humans need in order to perform the functions that sustain life. Sorghum contains relatively high levels of potassium (K) $(900-6957.67 \mathrm{mg} / \mathrm{kg})$ and phosphorus (P) (1498-3787.25 mg/kg), minerals known to facilitate muscle movement, maintain a healthy nervous system and build strong bones and teeth. B vitamins (0.1-19.9 mg/100 g) and vitamin E (1.38 mg/100 g) are also among the main essential vitamins reported [43].

Sorghum grains are known for their toughness compared to other cereals. The hardness of the sorghum grain is owed to the increased protein and prolamin content (3.6-5.1\%). The lysine quantity varies from 1.06 to $3.64 \%$. Studies of proteins in sorghum have indicated that the allocations of albumin-globulin, prolamin, and glutelin are approximately $15 \%, 26 \%$, and $44 \%$ of total nitrogen, respectively [43].

Pontieri et al. (2013) analyzed current knowledge on the development of functional non-gluten sorghum products, such as non-gluten bread, noodles, baby food, and beer [30]. The energetic value of $100 \mathrm{~g}$ of sorghum is around 400 calories, similar to corn and wheat. However, sorghum has a higher content of resistant starch. It also contains micronutrients like B-complex vitamins and minerals (potassium and phosphorus) [65]. 


\subsection{The Use in Brewing}

The use of maize and sorghum as adjuvants in brewing has been known for a long time. Recently, interest in and research on the use of these cereals and their malted forms to obtain new varieties of beer have increased.

\subsubsection{Maize}

Maize can be used as an adjuvant in brewing in many ways: as flour, groats, starch, expanded, extruded, cereals, corn syrup, etc. It is the most widely used adjuvant in Europe. In Brazil, it has been shown that the use of $30 \%$ maize as an adjuvant can reduce production costs by $8 \%$, though this value can vary based on local raw material prices and other production costs [66]. In this country, the use of substituents may not exceed $45 \%$ of the primitive extract [67].

Maize starch is widely applied (due to its high fermentability) as an adjuvant in the production of high-gravity beer [68]. Corn flakes or pre-gelatinized maize can be used to significantly reduce mashing time. Corn kernels produce a somewhat lower extract compared to other raw adjuvants (such as rice) due to the lower amount of dextrin in the wort after mashing. They also contain higher levels of lipids and proteins. It should be noted that the addition of corn derivatives has an important impact on the organoleptic properties of beer.

Poreda et al. (2014) obtained a beer with $10 \%$ and $20 \%$ maize addition, and analyzed the influence of these adjuvants on the production process and beer quality. Both adjuvant levels influenced the color of the wort: the intensity decreased (11.1 EBC for $10 \%$ maize addition and 10.5 EBC for 20\% maize addition). Dimethyl sulfide (DMS) and extract content were considerably lower in the wort produced with maize. Free amino nitrogen (FAN) content also decreased because - with the addition of corn-the content of hydrolysable proteins increased. The characteristics of the finished product were not considerably influenced [69]. Furthermore, as reported by Diakabana et al. (2013), corn beer has a low alcohol content, normal pH (about 4.5) and darker color due to the Maillard reaction [70].

In the future, it may be recommended that brewers/manufacturers use exogenous enzymes together with corn in order to enhance saccharification and amylolytic activity. The most convenient way to use corn in the beer industry is as an adjuvant because they are a source of carbohydrates. This is why maize granules are in common use. However, the process of obtaining malt from maize is quite expensive and difficult, though it is commonly used in brewing [7]. Rocha dos Santos Mathias et al. (2019) reported that the use of adjuvants and the exclusion of the proteolytic step from the mashing phase will lead to must with lower nitrogen compounds. Despite the fact that these are alternative steps to decrease production costs, they can influence yeast activity during brewing and affect the quality of the finished product [15].

Fumi et al. (2011) reported that when maize starch was used as an adjuvant, the phenolic content of the wort was lower compared to conventional wort [71]. Fumi et al. (2009) also reported that adjuvanted corn wort had a lower total nitrogen substance content than malt wort, and the free amine nitrogen was almost double that of malt [72]. However, Perez-Carrillo et al. (2012) reported that the content of free amine nitrogen in the wort increased due to the addition of protease, and the free nitrogen content in the corn wort $(60 \%)$ was twice as high as that discovered in sorghum wort (30\%) [73]. The starch granules in the maize endosperm were inserted in a protein matrix and enclosed in the cell walls; consequently, researchers are now looking for techniques to improve the conversion of maize starch into monoglucides [22].

He et al. (2018) analyzed the quality of adjuvants in the brewing of extruded maize starch and cooked maize starch. The aromatic substances of the beer obtained using extruded maize starch and cooked maize starch were examined via headspace solid-phase microextraction gas chromatography mass spectrometry. Eight volatile compounds in extruded maize starch and cooked maize starch beer were measured using gas chromatography. They concluded that both extruded maize starch and cooked maize starch could 
be used to produce beer-but the concentration of representative flavor substances was higher in the former than in the latter [22].

The potential use of maize in the beer industry as a malted cereal is low. Consequently, it is mainly utilized as an adjuvant. Zweytik and Berghofer (2009) obtained corn malt on a pilot scale to produce lower fermentation beer from $100 \%$ corn. They concluded that the finished product (the beer) was clear, with a light yellow color, and presented a good foam stability and flavor similar to normal beer [74].

Hernández-Becerra et al. (2020) reported that maize grains required fewer days to germinate compared to barley, which needed another day under the same experimental conditions. Maize grains are attractive for brewing because they germinate faster and have a high level of reducing sugars [17].

Table 2 summarizes data from the literature on the production of beer assortments based on maize or maize derivatives. For some varieties of beer, other ingredients are used as raw materials (for example, sorghum, wheat, and barley). To obtain these beer assortments, old manufacturing recipes and traditional processing are often used. However, technical and scientific advances in the brewin gindustry have optimized the process and increased the shelf life of finished products.

Table 2. Beer assortments in which maize is used as a raw material.

\begin{tabular}{|c|c|c|c|c|}
\hline $\begin{array}{c}\text { Beer Name } \\
\text { (Origin Country) }\end{array}$ & Raw Materials & Tehnological Process & $\begin{array}{l}\text { Finished Product } \\
\text { Characteristics }\end{array}$ & References \\
\hline $\begin{array}{l}\text { Sendechó } \\
\text { (Mexic) }\end{array}$ & $\begin{array}{l}\text { Blue maize, } \\
\text { chili Guajillo, } \\
\text { pulque }\end{array}$ & $\begin{array}{l}\text { Malting, grinding, } \\
\text { mashing, brewing, } \\
\text { fermentation }\end{array}$ & $\begin{array}{l}\text { Fermented fruit flavor, smells of } \\
\text { cooked vegetables, tortillas, } \\
\text { bread, dried fruit and dried chili, } \\
\text { amber-copper red color }\end{array}$ & {$[75,76]$} \\
\hline $\begin{array}{c}\text { Chicha de jora } \\
\text { (Argentina, Euador, } \\
\text { Peru) }\end{array}$ & Maize & $\begin{array}{l}\text { Malting, grinding, brewing, } \\
\text { lactic fermentation, } \\
\text { alcoholic fermentation }\end{array}$ & $\begin{array}{l}\text { Clear liquid, yellow color, } \\
\text { effervescent drink, and a low } \\
\text { alcohol content }(1-3 \%)\end{array}$ & {$[77,78]$} \\
\hline $\begin{array}{l}\text { Umqombothi } \\
\text { (Africa de Sud) }\end{array}$ & $\begin{array}{l}\text { Maize flour, } \\
\text { sorghum malt }\end{array}$ & $\begin{array}{c}\text { Mashing, brewing, } \\
\text { fermentation, filtration }\end{array}$ & $\begin{array}{l}\text { Opaque, pink in color, rich in B } \\
\text { vitamins, with a distinct aroma, } \\
\text { acid and a creamy consistency, } \\
\text { shelf life of } 2-3 \text { days }\end{array}$ & {$[79,80]$} \\
\hline $\begin{array}{l}\text { Sesotho } \\
\text { (Lesotho) }\end{array}$ & $\begin{array}{l}\text { Maize, sorghum and/or } \\
\text { wheat flour }\end{array}$ & $\begin{array}{l}\text { Grinding, mashing, lactic } \\
\text { fermentation, cooling, } \\
\text { alcoholic fermentation }\end{array}$ & $\begin{array}{c}\text { Opaque liquid, thin consistency, } \\
\text { distinct sour taste, } 3-5 \%(v / v) \\
\text { alcohol content, rich in B } \\
\text { vitamins }\end{array}$ & {$[81,82]$} \\
\hline $\begin{array}{c}\text { Chibuku } \\
\text { (Zimbabwe, } \\
\text { Tanzania, Zambia, } \\
\text { Ghana, Nigeria) }\end{array}$ & $\begin{array}{l}\text { Maize, sorghum, } \\
\text { sorghum malt, barley } \\
\text { malt }\end{array}$ & $\begin{array}{l}\text { Malting, grinding, brewing, } \\
\text { acidification, lactic } \\
\text { fermentation, alcoholic } \\
\text { fermentation }\end{array}$ & $\begin{array}{l}\text { Opaque brown-pink liquid } \\
\text { containing suspended and } \\
\text { dissolved solids }(3.6 \% \mathrm{w} / \mathrm{v}) \text {, } \\
\text { alcohol content of } 3-5 \% \text {, pH of } \\
\text { 3-4 and lactic acid levels of } \\
\text { approx. } 0.5 \mathrm{~g} / \mathrm{L}\end{array}$ & {$[83,84]$} \\
\hline $\begin{array}{c}\text { Tella } \\
\text { (Etiopia) }\end{array}$ & $\begin{array}{l}\text { Maize, barley, wheat, } \\
\text { Rhamnus prinoides L. }\end{array}$ & $\begin{array}{l}\text { Malting, grinding, brewing, } \\
\text { alcoholic fermentation }\end{array}$ & $\begin{array}{c}\mathrm{pH} 3.87-4.67 \\
\text { alcohol content }(\% v / v) 3.04-3.75 \\
\mathrm{CO}_{2} \text { content }(\%) 0.24-0.034\end{array}$ & {$[85,86]$} \\
\hline $\begin{array}{l}\text { Sekete } \\
\text { (Nigeria) }\end{array}$ & Sprouted maize & $\begin{array}{l}\text { Mashing, brewing, } \\
\text { acidification, lactic } \\
\text { fermentation, alcoholic } \\
\text { fermentation }\end{array}$ & $\begin{array}{l}\text { Dark brown color } \\
\text { alcohol content of } 1-3 \%\end{array}$ & {$[14,87]$} \\
\hline
\end{tabular}

In Mexico, the country in which corn originated, it occurs in a wide variety of pigmented grains, including white, yellow, red, purple, blue, and black. Over time, the inhabitants of Mexico have created several fermented drinks obtained from specific varieties of pigmented maize. These are widely known as corn beers [75].

Sendechó is a representative fermented drink obtained by the Mazahuas inhabitants of the Valley of Mexico. Their production technique is very comparable to the conventional technologies in use today for beer production. Sendechó is made using local ingredients, 
such as blue pigmented maize, which go through a process of malting with Guajillo chiliitself a customary ingredient in Mexican gastronomy. The wort obtained is fermented with pulque, a thick, white alcoholic beverage from the moorlands of Mexico, which is made by fermenting mead or the juice of various types of agave (Agave americana, Agave feroce Agave atrovirens, Agave salmiana and Agave mapisaga). The fermentation process for agave begins with spontaneous microorganisms such as yeasts, lactic acid bacteria, ethanol-producing bacteria and exopolysaccharide-producing bacteria [8].

The beer obtained with these varieties of pigmented maize is mainly characterized by aromas of fermented fruit, boiled vegetables, bread, tortillas, dried fruit and dried chilis. Romero-Medina et al. (2020) was the first to prove that ketones, anthocyanins, terpenes and volatile phenolic compounds were pertinent criteria for differentiation of maize beers. Anthocyanins can also be used as an indicator to determine whether a beer was obtained with pigmented maize malt. This could potentially be used as a quality characteristic in future studies. Studying the relations between sensory properties and chemical characteristics via multiple factor analysis (MFA) helped explain the influence of each malt type (red maize, blue maize and barley malt) on chemical characteristics and sensory attributes. Over 100 volatile compounds were quantified by headspace solid-phase microextraction coupled with gas chromatography mass spectrometry (HS-SPME/GC-MS). Terpenes and phenols were the groups of volatile compounds that better characterized the beers containing maize. The anthocyanin content of maize beers ensures colors in the amber, copper, and red families and can prevent the development of unwanted tastes and aromas [75].

Flores-Calderón et al. (2017) analyzed the chemical characteristics and antioxidant activity in three separate stages of the blue corn malt beer manufacturing process. The influence of adding caramel malt and various amounts of Guajillo hops and chili was analyzed, creating several types of blue maize malt beer. Upon completing statistical analysis, using ANOVA and multivariate methods, the best concentration of anthocyanins and antioxidant capacity was found in two varieties of beer (obtained with $85 \%$ corn malt and $15 \%$ caramel malt) [8].

Chicha de jora is a type of traditional corn beer (chicha) from South America. It is still widespread in Andean countries, where it is consumed for its nutritional properties [78].

Obtaining this product begins with the process of preparing maize malt from corn morocho. The corn is soaked for 3-8 days. For germination, the water is removed, and the grains are set for one to two weeks on the leaves of Baccharis latifolia (Chilca), Sambucus nigra (Sauco) or Alnus glutinosa (Aliso) at room temperature. After that, the germinated grains are dried for one to two weeks. Stones are traditionally used for the grinding process. The resultant flour is introduced into the water and boiled for 1-2 h. At this stage, some manufacturing recipes provide for the addition of other ingredients, e.g., chancaca corn, barley, sugar, cinnamon, cloves, wheat flour, quinoa, fava beans, herbs, or fruits. Fermentation takes place in several containers, depending on the capacity of the chichería, and is frequently an uncontrolled procedure that can take anywhere from $24 \mathrm{~h}$ to 15 days. To start the fermentation process, according to ancient practices, ceramic vessels called tomin are used. These vessels are made of a porous material that helps the adhesion and multiplication of microorganisms. During fermentation, particles of corn from the grinding process are continuously drained to obtain borage which can then be reused as the inoculum for subsequent productions. The addition of chicha borra in the second stage of fermentation gives the beverage a higher alcohol content by volume.

Biochemical and physiological research has established the main role of the genus Lactobacillus and genus Leuconostoc in the fermentation process. Recent molecular studies utilizing next-generation sequencing methods have shown that lactic acid bacteria and yeast are the main populations accountable for the organoleptic properties of this drink. The data from the literature have expanded knowledge on the microbiota of this fermented beverage in different stages of the technological process, allowing the detection of minority species of bacteria or difficult-to-grow microorganisms. Although corn chicha is primarily 
brewed in northwestern Argentina, Brazilian rice chicha and cassava chicha from Ecuador have also been researched. Peruvian chicha has not been studied as closely or as often.

Basi et al. (2020) analyzed twenty-seven chicha samples from fourteen different chicherias in seven regions of Peru. They showed that fermentation was produced by a select group of microorganism species, dominated by lactic acid bacteria groups, which promote health and determine the hygienic and beneficial qualities of the finished product [77].

Umqombothi is a traditional South African beer. It is opaque, pink in color, and rich in $B$ vitamins, with a distinct, acidic aroma and a creamy consistency. To produce it, corn flour is combined with sorghum malt and water. The mixture is then boiled to a soft consistency and cooled for approximately $6 \mathrm{~h}$. After adding sorghum malt and umqombothi from a previous batch, the mash is left to ferment for about $18 \mathrm{~h}$, after which the mixture is filtered. Umqombothi is characterized by a short shelf life ( $2-3$ days) and is consumed as a product in which fermentation is not complete. It is common, especially among rural black populations in South Africa. Umqombothi is produced mainly by women, either for social events or for sale $[79,80]$.

Sesotho is a well-liked beer, obtained through spontaneous fermentation, which originated from Lesotho (South Africa). It is produced from ground corn, wheat, sorghum flour, or a combination of these. This beverage is opalescent, has a low consistency and a distinct acidic taste. Sesotho is produced mainly in rural households or for small-scale commercial purposes. It is also used as a beverage for funerals, weddings, and cultural ceremonies. Lactic acid bacteri (such as Lactobacillus, Enterococcus, Leuconostoc, Pediococcus and Wiesella) and yeasts of the genus Saccharomyces are in common use in all beer factories where Sesotho is produced [81]. Some factories produce this beer using $50 \%$ barley malt, $34 \%$ unmalted corn and $16 \%$ unmalted wheat. Krstanovic et al. (2020) analyzed the colloidal stability and shelf life of this type of beer and concluded that it should be stabilized by methods that guarantee the elimination of haze inducers [88].

Sesotho was traditionally made using only sorghum and wheat flour. According to information reported from women who produced sesotho, sorghum and wheat flour are traditionally mixed together in equal amounts, after which cold water is added to obtain a rigid consistency. Hot water is then introduced to obtain a thin porridge, which is cooled to about $30-35{ }^{\circ} \mathrm{C}$. After the addition of a traditional liquid starter known as tomoso, the mixture is left to ferment, either overnight or for $24-48 \mathrm{~h}$, depending on the ambient temperature. It is then boiled for $2-3 \mathrm{~h}$ and cooled to $30-35^{\circ} \mathrm{C}$. A solid starter culture called moroko (using scraps from previous fermentations) is added and the mixture is fermented for another $24-48 \mathrm{~h}$. It is then filtered to remove coarse particles to obtain the finished beer [82].

Chibuku is the best-known opaque beer made in Zimbabwe. Over 420 million L are produced in twenty breweries annually. Chibuku is also known as hwahwa, doro, utshwala or mhamba in various parts of Zimbabwe. Other brands are made locally, such as Pungwe, Simba, Go-beer and Ingwebu. This beer was first manufactured in Zimbabwe in 1962 by Delta Beaches Breweries, after originating in Zambia in the 1950s. Chibuku is currently brewed using advanced technology, unlike many traditional beers from rural regions of Zimbabwe, Zambia, Tanzania, Nigeria, Ghana and other African states. This beer is obtained from corn, sorghum, barley malt, sorghum malt, water, lactic acid and superior fermentation yeast of the species Saccharomyces cerevisiae [83].

Chibuku is an opaque brown-pink beverage containing dissolved and suspended solid substances $(3.6 \% w / v)$, with an alcoholic strength of 3-5\%, a pH of 3-4 and a lactic acid content of about $0.5 \mathrm{~g} / \mathrm{L}$. In essence, the process of obtaining the finished product consists of lactic fermentation and alcoholic fermentation. This beer is sold at retail while still microbiologically active, so lactic acid bacteria can spoil the product. Useful microorganisms continue to multiply even after acceptable levels of alcohol and lactic acid have been obtained. The product becomes unacceptable when lactic acid levels reach $0.5 \%(v / v)$ and other metabolic substances have accumulated [84]. 
Opaque beer has been a sociocultural drink in African for over a century. Depending on the geographical location, these beers bear different names. Opaque beers are called burukutu or pito in Ghana and Nigeria, chibuku in Zimbabwe, utshwala in South Africa, ikagage in Rwanda, mtama in Tanzania and tchakpalo in Ivory Coast and Togo. The technology used to produce these opaque beers differs slightly from country to country, depending on the local raw materials available to them. Some use sorghum, while others may use millet, cornmeal, or even bananas. These beverages are a completely natural and nutritionally balanced product and rightly considered a liquid food and an alcoholic drink. Perhaps this is the reason why Africans-especially in rural regions-consume them in great quantities. The consumption of these beers often occurs while the fermentation state is still active [83].

Tella is a beer that is widely brewed and consumed in both rural and urban regions of Ethiopia. It is mainly obtained from cereals e.g., maize (Zea mays L.), wheat (Triticum aestivum Z.) and barley (Hordeum vulgare L.). In addition to cereals, Rhamnus prinoides L., which is known as gesho in Amharic, is used to add a special flavor to the finished product. It is also used as an antiseptic agent against bacteria. Alcohol is produced by Saccharomyces cerevisiae, but it is not able to metabolize starch. However, Andualem and Gessesse (2013) showed that yeasts other than Saccharomyces cerevisiae should be avoided in the tella production process, as their role in converting starch into fermentable sugar is reduced compared to malt amylase [85].

In the process of preparing tella, various substrates, including malt, enkuro (roasted dry corn ground into fine flour, mixed with water and boiled), kita (bread made from grain flour such as corn, wheat, or barley, separately or in the mixture), and derokote (fried maize, wheat or barley grains) are used as a source of carbon in fermentation. Malt amylases may not be sufficient to break down starch molecules into fermentable sugars in different substrates, as kita, enkuro and derokote are produced from cereals with a high starch content. Thus, various microorganisms from environmental sources may contribute to amylases and increase the efficiency of the conversion of starch from malt and adjuvants into maltose and other fermentable sugars [86].

Sekete is a drink made from germinated corn grains. It has a low alcohol content. This beer is commonly consumed by native people in rural areas in western Nigeria. Very little scientific research has been done on this beer. Studies show that after fermentation, the mineral content (phosphorus, magnesium, potassium, and sodium) is decreased, while the content of some vitamins (riboflavin and niacin) is increased. This beer is a rich source of important amino acids like tyrosine, alanine, lysine and leucine, but it is deficient in arginine and proline. The drink exhibits high acidity. It contains species of bacteria of the genus Lactobacillus and yeasts of the genus Saccharomyces, in whose technological processes, lactic fermentation predominates- to the detriment of alcoholic fermentation. The commonly experienced relaxing, medicinal, and stimulating effects of the drink may be the result of its microbial profile, acid content and microorganism activity. Obatolu et al. (2016) recommended fortifying and sweetening sekete to increase the overall acceptability of the drink [89].

\subsubsection{Sorghum}

Outside of Mexico and Niger, sorghum has not been widely used as an adjuvant, although its potential has been promoted. Sorghum semolina offers several advantages in beer brewing, including short boiling time, easy filtration, high extract content and highly nutritious wort [90].

In 2017, sorghum dominated the non-gluten beer market; sorghum beer accounted for $37.9 \%$ of the total volume of non-gluten beers produced. Non-gluten beer is not only marketed to people with gluten intolerance. Many are consumed by people interested in new drinks and new products. In this way, the market for non-gluten beer consumers can be significantly expanded. It has been found that women are a special target group, because the incidence of celiac disease is higher among women (60\% of adult patients) and 
because women are often more concerned with a healthy lifestyle, including in their diet. The global non-gluten-beer market is projected to grow to $\$ 18.7$ billion by 2025 , with an annual growth rate of $16.3 \%$, according to a report published by Fior Markets [15].

Goode and Arendt (2003) used unmalted sorghum as an adjuvant in 50\% barley malt and found that a good quality finished product was obtained, comparable to beer obtained from 100\% barley malt [91]. Ogbonna (2011) recommended the use of sorghum as an adjuvant to barley malt at $50 \%$, and showed that it was possible to obtain beer from $100 \%$ sorghum malt [92]. In other research, it was argued that the use of $40 \%$ sorghum as an adjuvant in brewing did not significantly influence the quality of the finished product. Other researchers have produced lager beer with $25 \%$ sorghum adjuvant and concluded that a good quality beer was obtainable when barley malt was substituted with up to $25 \%$ sorghum [90].

Beta et al. (1995) analyzed the malting characteristics of several varieties of sorghum with characteristics similar to commercial barley malt, suggesting that they might produce different qualities of malt [93]. Chandra, Proudlove, \& Baxter (1999) reported that the texture of the endosperm affected malting, influenced water absorption, and impacted the enzymatic process [94]. Oyewole \& Agboola (2011) showed that malting losses were very high for tropical grains [95].

Eneje et al. (2004) and Oyewole \& Agboola (2011) studied the qualities of rice, sorghum, millet and maize malt and reported that sorghum and millet malts were more suitable for use in food formulation, while maize - which bears some similarity to barley in compositional characteristics - could be used as a substitute for conventional malt in beer brewing $[54,95,96]$.

The use of sorghum malt in beer manufacture has led to some difficulties, largely due its low amylolytic activity (which is insufficient for complete saccharification), high gelatinization temperature, and low content of free amino nitrogen. Sorghum malt exhibits higher $\alpha$-amylase activity, but lower $\beta$-amylase activity, compared to barley malt. Reduced enzymatic activity can lead to insufficient production of fermentable carbohydrates, high dextrin content, and increased viscosity $[97,98]$. The gelatinization temperature of sorghum malt is limited by kafirin [99], and thus the hydrolysis of starch into fermentable sugars is only partially completed. Therefore, in order to avoid technological challenges, the use of sorghum in brewing requires an adequate malting process. Otherwise, it is recommended to use exogenous enzymes to produce sorghum beers [7].

Espinosa-Ramírez et al. (2014) studied the effect of the addition of $\beta$-amylase and amyloglucosidase during sorghum mashing. They produced a beer with higher alcohol content [100]. Urias-Lugo and Salvidar used amyloglucosidase to achieve improved production efficiency of wort and its filtration rate, resulting in a higher percentage of ethanol [101]. However, the alcohol content of sorghum beer was 1.1\% lower than barley malt beer. The color, $\mathrm{pH}$ and content of free amino nitrogen were not affected by the addition of amyloglucosidase. To reduce these deficiencies, Aspergillus oryzae can be added; it has been shown to improve the malting characteristics of sorghum. By using this adjuvant, $\alpha$-amylase was positively affected. There were no differences for $\beta$-amylase [7].

In Africa, sorghum is traditionally the most important raw material in beer production, both malted and as an adjuvant $[102,103]$. The presence of sorghum beers on the market is proof of the potential of this cereal in brewing. However, in order to improve the sensory properties of the finished product, it is necessary to obtain a quality sorghum malt or to use it in combination with other cereals [7,104].

In Africa, different types of traditional fermented beverages have been described, commonly named opaque beers or sorghum beers. These beverages have both sociocultural and nutritional value. They are known as dolo in Burkina Faso, ikagage in Rwanda, amgba in Cameroon, pito or burukutu in Nigeria and Ghana, merissa in Sudan, doro or chibuku in Zimbabwe, bili bili in Chad, mtama in Tanzania, tchapalo in Ivory Coast, Togo and Benin, and kaffir in South Africa. These beverages play a central role in these cultures and are a significant part of the diet for a growing part of the population. 
The presence of nonspecific microorganisms in the traditional starter cultures of some of these beverages can make it more difficult to monitor the fermentation process-this, in turn, can lead to finished products of variable quality. That is why it is recommended to use pure starter cultures to reduce organoleptic variations and decrease the risk of contamination with pathogenic microorganisms. Controlled fermentation also increases the chances of preserving traditional sorghum beer, giving it a longer shelf life. Pasteurization would also solve the issue of sorghum beer's relatively short shelf life, which is a problem for the brewing industry. As a potential alternative to the use of synthetic preservatives, pasteurization of beer could be combined with plant extracts. It is well known that the main determinant factor in the deterioration of beverages is the presence of Gram-negative bacteria, Gram-positive bacteria, and molds [84].

In African countries, sorghum beer is generally consumed at festivals, weddings, prayers, rituals, birth ceremonies, and funeral rituals. For example, in Burundi and Rwanda, the consumption of this beer marks the beginning of the handing over of the dowry during traditional marriages. The families in question share pleasures around a clay pot of sorghum beer. Sorghum beer signifies the connection between the couple and their families. Meetings and community work also often end with the consumption of this beer. Sorghum beer contributes significantly to the diets of many persons in developing countries and is largely consumed by the poor. Sorghum beer has a high content of B vitamins, such as riboflavin, nicotinic acid, and folic acid. It is also rich in amino acids, and in mineral substances such as calcium, sodium, potassium, magnesium, iron, and zinc. In general, sorghum beer has a higher nutritional value than European barley beers, due to its high content of lactic acid bacteria, yeast and other suspended materials [13]. Sorghum beer is considered both a food (energizer) and an alcoholic drink. This may be why Africans, especially in rural regions, consume fairly lare quantities of sorghum beer [83].

Nigeria produces over 900 million liters of beer annually, and most of it is made from sorghum. This cereal has crossed to parts of Eastern and Southern Africa, the United States, Mexico, Cuba, and Israel (where sorghum beer is also produced) [30,105].

In Togo, about $60 \%$ of national sorghum production is used to produce two types of sorghum beer: Tchoukoutou and Tchakpalo. The manufacturing and marketing of this beer remains primarily the purview of Togolese women, from which they derive significant earnings. Sorghum beer is a key socioeconomic factor in northern Togo, where it is served in large quantities on holidays. Sorghum beer is also used in traditional rituals and religious ceremonies [84].

Clear sorghum lager beers have reportedly been manufactured in many parts of the world. Sorghum lager beers have been produced in Mexico and Cameroon. In Sri Lanka, specialists analyzed sorghum varieties in order to select the most appropriate type for obtaining a conventional lager. In the USA, sorghum has been used since the 1980s as an adjuvant in the preparation of lagers. The most significant progress in the production of sorghum beer has probably been achieved in Nigeria. Due to the government's 1988 ban on importing barley malt, local brewers were compelled to use alternative native cereals, such as corn and sorghum, as substitutes for malted barley [90].

Ogbonna and Adejemilu (1992), in a review of sorghum beer production, discussed the technological difficulties associated with sorghum malting and sorghum beer production [106]. Comprehensive reviews on the preparation of sorghum lager beer, especially sorghum malt, were conducted by Agu and Palmer (1998), Owuama (1999) Schnitzenbaumer, Arendt (2014), and Embashu et al. (2019) [21,104,107,108]. Unmalted sorghum grain and commercial enzymes are more sustainable for use in brewing-mainly because malted sorghum has several inconveniences, including limited protein modification, insufficient diastatic power, high malt losses, high malting costs, and the necessity to improve the mash with exogenous enzymes [90].

The main problems in the manufacture of sorghum beer are the reduced diastatic power of the resulting malt (especially the deficiency in $\beta$-amylase activity) and the high gelatinization temperature of sorghum starch, in contrast to barley starch [109]. Espinosa- 
Ramirez et al. (2013) successfully produced lager beers from several varieties of sorghum malts and non-gluten adjuvants. These were also supplemented with amyloglucosidase and $\beta$-amylase $[98,100]$.

Pilot-scale beer $(1000 \mathrm{~L})$ was produced using raw malted sorghum $(50 \%$ of the total wet weight of the grains) and barley malt (50\% of the total wet weight of the grains) as raw materials. The raw materials were subjected to the mashing operation with rests at temperatures of $50{ }^{\circ} \mathrm{C}, 95^{\circ} \mathrm{C}$ and $60^{\circ} \mathrm{C}$. Organoleptic analysis showed that there were no noteworthy differences in terms of aroma, taste and clarity between sorghum beer, the control beer, and commercial barley beer. However, it was found that sorghum beer differed significantly from the control and barley beers in the color, taste and stability of the foam [90].

Table 3 summarizes data from the literature on obtaining beer assortments that use sorghum as a basic raw material.

Table 3. Beer assortments in which sorghum is used as basic raw material.

\begin{tabular}{|c|c|c|c|c|}
\hline $\begin{array}{c}\text { Beer Name } \\
\text { (Origin Country) }\end{array}$ & Raw Materials & Tehnological Process & $\begin{array}{l}\text { Finished Product } \\
\text { Characteristics }\end{array}$ & References \\
\hline $\begin{array}{c}\text { Burukutu/Otika } \\
\text { (Nigeria, Niger, Ghana) }\end{array}$ & Sorghum & $\begin{array}{l}\text { Malting (steeping, } \\
\text { germination), milling, } \\
\text { mashing, boiling, } \\
\text { fermentation, maturation }\end{array}$ & $\begin{array}{l}\text { Viscous, opaque, light brown } \\
\text { liquid, alcohol content } \\
\text { approx. } 4 \%(v / v) \text {, sour taste, } \\
\text { pH }=3.3-3.5\end{array}$ & {$[42,87]$} \\
\hline $\begin{array}{c}\text { Pito } \\
\text { (Ghana, Togo, Nigeria) }\end{array}$ & Sorghum & $\begin{array}{l}\text { Malting, grinding, mashing, } \\
\text { brewing, lactic fermentation, } \\
\text { alcoholic fermentation }\end{array}$ & $\begin{array}{l}\text { Sour taste, characteristic, } \\
\text { alcohol content } 3-5 \%(v / v)\end{array}$ & [110-113] \\
\hline $\begin{array}{c}\text { Tchapalo } \\
\text { (Coasta de Fildes, Togo, } \\
\text { Benin) }\end{array}$ & Sorghum & $\begin{array}{l}\text { Lactic fermentation, } \\
\text { alcoholic fermentation }\end{array}$ & $\begin{array}{l}\text { Non-alcoholic beer, turbid, } \\
\text { shelf life } 3 \text { days }\end{array}$ & [114-118] \\
\hline $\begin{array}{c}\text { Bantu } \\
\text { (Africa de Sud) }\end{array}$ & Sorghum & $\begin{array}{l}\text { Malting, grinding, mashing, } \\
\text { lactic fermentation, alcoholic } \\
\text { fermentation }\end{array}$ & $\begin{array}{c}\text { Turbid liquid, alcohol } \\
\text { content } 3-4 \%(v / v) \text {, sour } \\
\text { taste, brown-pink color, rich } \\
\text { in B vitamins }\end{array}$ & [119-122] \\
\hline $\begin{array}{c}\text { Dolo } \\
\text { (Burkina Faso, Benin, } \\
\text { Rwanda) }\end{array}$ & Sorghum & $\begin{array}{l}\text { Malting of red sorghum } \\
\text { grains, crushing, mashing, } \\
\text { cooking, lactic fermentation, } \\
\text { filtration, boiling, alcoholic } \\
\text { fermentation }\end{array}$ & $\begin{array}{c}\text { Turbid liquid, alcohol } \\
\text { content } 1-5 \%(v / v), \\
\text { sweet-sour taste, fruit flavor }\end{array}$ & [123-126] \\
\hline $\begin{array}{l}\text { Bili bili } \\
\text { (Ciad) }\end{array}$ & Sorghum & $\begin{array}{l}\text { Malting, mashing, boiling, } \\
\text { souring, and fermenting }\end{array}$ & $\begin{array}{c}\text { Turbid liquid, brown-pink } \\
\text { color, sour taste, fruity, } \\
\text { alcohol content } 1-8 \%(v / v), \\
\text { low in carbohydrates and } \\
\text { high in protein }\end{array}$ & [104,127-130] \\
\hline $\begin{array}{l}\text { Omalovu } \\
\text { (Namibia) }\end{array}$ & Sorghum, millet & $\begin{array}{l}\text { Malting, drying, milling, } \\
\text { souring, boiling, mashing, } \\
\text { straining, alcoholic } \\
\text { fermentation }\end{array}$ & $\begin{array}{l}\text { Unpasteurized beer, opaque, } \\
\text { red-brown or cream color, } \\
\mathrm{pH}=3.06-4.34 \text {, alcohol } \\
\text { content } 0.18-4.05 \%(v / v)\end{array}$ & {$[104,131]$} \\
\hline
\end{tabular}

Burukutu is another fermented alcoholic drink produced from sorghum grains, having an alcohol content of about $4 \%(v / v)$. This beer is a viscous, opaque liquid, due to the suspended solids and yeast. It is light brown in color, with an acidic taste caused by the presence of lactic acid and a $\mathrm{pH}$ of 3.3 to 3.5. It is frequently sold in Mammi markets (which are attached to soldiers' barracks in Nigeria) and in northern Niger [87]. Burukutu contains vitamins including potassium, magnesium, iron, manganese, and calcium, and contains about $26.7 \mathrm{~g}$ of starch and $5.9 \mathrm{~g}$ of protein per liter. This regional drink is known as tchoukoutou in Benin or Togo, burukutu or otika in Nigeria, bilibili in Chad, pito in Ghana, dolo in Burkina Faso, mtama in Tanzania, and kigage in Rwanda. Technological processes are highly inconsistent and dependent on the region in which the beverage is produced. In 
general, the brewing process involves malting, soaking, germination, grinding, mashing, boiling, fermentation and maturation [42].

Pito is part of many native African beers collectively called sorghum beer or opaque beer. It is a light alcoholic drink commonly found in many regions of Africa. It is produced from sorghum and is known under different names, depending on the tribe or locality. Ghana produces some of the most well-liked types of ethnic pito, such as Frafra pito, Dagarti pito, Kasena pito, Kusasi pito and Grushie pito. In general, pito has a unique sour taste and holds 3-5\% alcohol by volume. The technological process consists of two types of fermentation: lactic fermentation and alcoholic fermentation. Pito brewing is still artisanal, done primarily by women, and the quality of the product differs greatly producer to producer and even batch to batch.

The process of obtaining pito varies depending on the ethnic group or tribe. Generally, sorghum grains are soaked in water, left to germinate for 4-6 days and dried in the sun for two days or more. The dried malt is coarsely ground and mixed with water. Clarifying agents (such as crushed okro stalk bark) are added, and mixed with the suspension, which is then left to stabilize and clear. The obtained mash is boiled, followed by cooling and filtration. the obtained must is subjected to boiling, cooling, and clarification. The clear must is then decanted and inoculated with yeast to ferment. Finally, pito usually has a low brewing yield of $47.28 \pm 11.74 \%$ and an extract recovery yield of $62.21 \pm 15.44 \%$ compared to a brewing yield of $76 \%$ and an extract recovery yield of $97 \%$ for lager beer brewed in industrial beer factories [108].

Tchapalo is a traditional nonalcoholic, opaque beer that contains suspended solids and yeast and is typically obtained from sorghum in Ivory Coast. This traditional drink is produced in a two-step process comprising lactic fermentation to generate the sweet wort followed by alcoholic fermentation. This beer is typically consumed by women, children and those who want to drink beer without alcohol [114-116].

Tchapalo and sweet wort contain several nutritional substances that help improve consumer diets. Additionally, popular opinion has attributed medicinal benefits to this drink, including laxative, antimalarial and antihemorrhoidal effects, whilst scientific research has indicated that it may potentially work against diabetes, cardiovascular diseases, and cancer. This type of drink is consumed at different African ceremonies (e.g., marriage, birth, baptism, etc.) and festivals, and is also a source of revenue for female brewers. Nevertheless, tchapalo and sweet wort is often produced under deplorable hygienic conditions, using rudimentary equipment and a large amount of work. Consequently, the finished products have a short shelf life (3 days), and the quality of the product differs widely [117,118].

Bantu is a traditional sorghum beer made in South Africa. It is often turbid and contains yeast with a persistent sour taste. It is brownish-pink. Higher $\mathrm{pH}$ levels produce a more pronounced pink color. Most traditional sorghum beers have low alcohol content ( $3 \%$ to $4 \%$ ). Many traditionally prepared sorghum beers also contain maltotriose, the last fermented sugar in yeast during fermentation. Some amino acids and peptides are also present. Cassava root is also used throughout Africa as an alternative to cereals, in addition to sorghum malt in brewing [119-122].

Dolo is a well-known traditional beer from Burkina Faso. This beer is prepared from the Sorghum bicolor variety of sorghum; in some localities, millet, and maize are used as adjuvants. In Burkina Faso, yeasts and lactic acid bacteria are the main microorganisms used in making dolo beer. Dolo yeast—called rabilé in Burkina Faso, kpètè-kpètè or otchè in Benin, and umusemburo in Rwanda-is used as a spice and an important source of protein for some communities in Burkina Faso. Dolo yeast is generally collected from the bottom of the fermentation vessel, after a period of $12-13 \mathrm{~h}$ of fermentation. This beer is frequently filtered but remains turbid and has a blend of sweet/acidic tastes and fruit flavors. It contains $1-4 \% v / v$ alcohol. The traditional production of this beer involves malting the red sorghum grain, followed by the crushing, mixing, boiling, lactic fermentation, filtration, boiling and alcoholic fermentation of the wort. The color of the cereals and sorghum flours used plays a significant role in dolo's acceptance by consumers [123-126]. 
Bili bili is a traditional Chadian beer that has a relatively low concentration of alcohol and is obtained without hops. This beer has a slightly acidic taste and is consumed unfiltered (containing particles), especially in rural areas. It is produced by lactic fermentation, boiling, mashing, filtration, and alcoholic fermentation. The lactic fermentation process is achieved by inoculating a suspension of ground malt in water with Lactobacillus leichmannii. Sorghum beer is more viscous than commercial beer. The color of this beer is intense, depending on the $\mathrm{pH}$ of the finished product $[53,104]$.

Omalovu is one of the most popular beers in Namibia. Producing this type of beer is a traditional process and is contingent on the skills of the producer. It is brewed only locally. It is obtained from white or red sorghum, the latter being preferred, possibly due to the sensory properties of color, bitterness and astringency that it can bring to beer. Omalovu is not commercially manufactured, but it is freshly produced and used to supplement household income when sold on open markets. During important events and holidays, this beer is prepared in batches of 20-30 L. Omalovu can be produced with malted sorghum flour and water, though malted millet flour can also be used. The quality of this beer is inconsistent, due to the variable malting process and uncontrolled technological conditions. Nevertheless, with advancements in the malting and brewing process, the possibility of producing omalovu on an industrial scale is greatly increased [104].

\subsection{Other Uses}

In general, cereals have multiple uses, and maize and sorghum are not exceptions to this rule.

Maize or corn (Zea mays L.) is among the most significant crops in the world from an energy point of view. Historically, the demand for maize has been determined by the starch industry and the bird feed industry. More recently, research has studied the use of other parts of this cereal. Maize outperforms other ingredients in bioethanol production, with respect to generated starch content levels (over 72\% of the U.S.), crop yield and ethanol yield $[14,36]$.

Globally, corn is mainly used for animal feed (64\%), with significant amounts used as human food (16\%), industrial starch and beverages $(19 \%)$, and seeds (1\%). Corn has reached a significant position as an industrial crop; $83 \%$ of its products are used in the starch and feed industry $[8,38]$.

Today, it is also considered a vital cereal in several countries, especially in Asia, Central/South America, and Africa. Maize serves as the basic ingredient for thousands of products, including: alcohol, oil, protein, beverages, pharmaceuticals, food sweeteners, food grains, cornflakes, corn flour, starch, syrups, dextrose, cosmetics, films, textiles, paper, biofuels, and more. As one of our fundamental food crops, corn can be used in various forms, including: corn flour for confectionery use, semolina (in soup), ground corn (in animal feed), and fried corn. Corn is also cooked or boiled as a form of porridge [132-134].

Around $40-75 \%$ of animal feed is maize; thus, maize grains are essential for meat, eggs, and dairy products, providing the animals with energy and other essential for survival. Several beverages, including alcoholic beverages, have been obtained from maize, both locally and industrially $[135,136]$. Edible oils obtained from maize seeds contain a high level of natural antioxidants, and are used in the preparation of salads or for cooking household foods. They provide nourishing nutrients for the human body [137,138]. Roasted seeds are used as a coffee substitute. Maize starch is also well known for its use in the cosmetics industry, and in the pharmaceutical industry, where it is used to create edible packaging $[139,140]$. Maize seeds are essential in the manufacture of alcohol and stem fibers for papermaking. Industrial uses of maize have grown and diversified over many years, ranging from mixed feed manufacturing, dry milling, wet milling, distillation, and fermentation. Fermentation industries produce butyl alcohol, ethyl alcohol, propyl alcohol, lactic acid, acetic acid, acetaldehyde, acetone, citric acid, glycerol, and whiskey, among other relevant products which are currently flooding the industrial market [34]. 
Sorghum is also utilized for many purposes. This cereal is traditionally grown as a food source for people and animals. Because it is grown in most African and Asian countries, it has been used in many types of food (often indigenous) as well as alcoholic and nonalcoholic drinks. People of the savannah regions of Africa and Asia generally consume sorghum wine, or soft beverages such as kunu-zaki.

Many developing countries (especially Africa) use over $78 \%$ of their sorghum crops for food, with approximately $14 \%$ used for animal feed and $7 \%$ for diverse uses [43].

For western countries, where $40 \%$ of the global sorghum crop is produced, this cereal is mostly used as fodder or for ethanol production. More recently, research has focused on the benefits of sorghum in human food, including its vast nutritional potential and its impact on the quality of life of people with celiac disease. In addition, the growing demand for gluten-free foods and drinks has led to numerous studies of sorghum as a crop for human consumption. Various sorghum-based products have been created, including bakery products, pasta, and biscuits. Moreover, innovative sorghum hybrids with tanninfree white cereals (often referred to as food-grade sorghum) have been developed for gluten-free food markets [141-145].

\section{Perspectives}

The development of brewing from unconventional raw materials is always a major challenge for researchers and specialists in the field. There is currently growing concern about the real and potential failures of industrial crops, including important brewing cereals such as barley and wheat. Climate change is adding to those concerns. Research is needed to identify new ingredients (e.g., maize and sorghum) in the brewing industry [45].

Beer is the most important part of the global alcoholic beverage market and is projected to grow at a compound annual growth rate (CAGR) of 5.2\% during the next period (2021-2026). An upward trend has also been noted for consumers' preferences for beers obtained from new ingredients and with innovative flavors [146]. As technology advances, more economic and technical criteria will be taken into account-including the consumer response to new beverages. Maize and sorghum are destined for wider consumption in the future, in the form of various foods and nonalcoholic and alcoholic beverages.

In the beer industry, research into gluten-free beer assortments and new nonalcoholic or low-alcohol beers will continue. Additionally, research will continue on increasing beers' shelf lives while complying with current food safety regulations.

More research is needed on germination and the physicochemical properties and enzymatic activities of sorghum and maize in order to obtain malt comparable to barley malt in quality [17].

Future research is needed to develop a non-gluten beer with the technological and sensory characteristics - as well as the foam stability, wort fermentability, and final tasteof beers brewed using conventional raw materials. It is recommended to combine different gluten-free raw materials with the use of exogenous enzymes to optimize production recipes and obtain new varieties of beer with desirable qualities [30].

It is necessary to improve the technologies involved in the production and preservation of beer from unconventional raw materials in order to maintain their nutritional and marketable qualities.

\section{Conclusions}

The studies undertaken demonstrated the real potential benefits of using maize and sorghum in the brewing process, whether as simple adjuvants or via the brewing of beers made from $100 \%$ sorghum or maize malt.

Maize is a versatile money crop and is adaptable to various climatic conditions; globally, it is known as the queen of cereals. Sorghum is genetically close to corn, and is also called the camel plant due to its resistance to extreme drought conditions. Sorghum is also a vital staple food in many semi-arid areas of the developing world. 
There are some limitations in the use of these two cereals: maize has bare grains and lacks a husk (which would act as an adjuvant for filtration). It also has a low level of enzymatic activity. The structure of the sorghum grain is similar to maize; it has no shell, and the aleurone layer inhibits the flow of enzymes. Moreover, the development of amylolytic enzymes during the germination of maize and sorghum is lower than in barley.

In countries around the world, craft and functional beer brewing has revived old varieties and created new ones. Specialist brewers have worked to advance novelty beers that exhibit a complete and rich taste through efficient processing. These new beverages are created using various ingredients, and often involve modifications of the brewing process.

In conclusion, industrial and scientific research can promote innovation by creating new assortments of beer using maize and sorghum. This, in turn, could have a significant impact on product quality improvements.

Author Contributions: A.D., M.E.C., A.C. and G.G.C. contributed equally to the collection of data and preparation of the paper. All authors have read and agreed to the published version of the manuscript.

Funding: This research received no external funding.

Conflicts of Interest: The authors declare no conflict of interest.

\section{References}

1. Fox, G. The brewing industry and the opportunities for real-time quality analysis using infrared spectroscopy. Appl. Sci. 2020, 10, 616. [CrossRef]

2. Albanese, L.; Ciriminna, R.; Meneguzzo, F.; Pagliaro, M. Gluten reduction in beer by hydrodynamic cavitation assisted brewing of barley malts. LWT 2017, 82, 342-353. [CrossRef]

3. Humia, B.V.; Santos, K.S.; Barbosa, A.M.; Sawata, M.; Mendonça, M.D.C.; Padilha, F.F. Beer molecules and its sensory and biological properties: A review. Molecules 2019, 24, 1568. [CrossRef]

4. Rošul, M.Đ.; Mandić, A.I.; Mišan, A.Č.; Đerić, N.R.; Pejin, J.D. Review of trends in formulation of functional beer. Food Feed. Res. 2019, 46, 23-35. [CrossRef]

5. Chetrariu, A.; Dabija, A. Pre-treatments used for the recovery of brewer's spent grain-a minireview. J. Agroaliment. Process. Technol. 2020, 26, 304-312.

6. Habschied, K.; Živković, A.; Krstanović, V.; Mastanjević, K. Functional beer-A review on possibilities. Beverages 2020, 6, 51. [CrossRef]

7. Cela, N.; Condelli, N.; Caruso, M.C.; Perretti, G.; Di Cairano, M.; Tolve, R.; Galgano, F. Gluten-free brewing: Issues and perspectives. Fermentation 2020, 6, 53. [CrossRef]

8. Flores-Calderón, A.M.D.; Luna, H.; Escalona-Buendía, H.B.; Verde-Calvo, J.R. Chemical characterization and antioxidant capacity in blue corn (Zea mays L.) malt beers. J. Inst. Brew. 2017, 123, 506-518. [CrossRef]

9. Donadini, G.; Fumi, M.D.; Kordialik-Bogacka, E.; Maggi, L.; Lambri, M.; Sckokai, P. Consumer interest in specialty beers in three European markets. Food Res. Int. 2016, 85, 301-314. [CrossRef]

10. Betancur, M.I.; Motoki, K.; Spence, C.; Velasco, C. Factors influencing the choice of beer: A review. Food Res. Int. 2020, 109367. [CrossRef]

11. Chetrariu, A.; Dabija, A. Brewer's spent grains: Possibilities of valorization, a review. Appl. Sci. 2020, 10, 5619. [CrossRef]

12. Zhang, T.; Zhang, H.; Yang, Z.; Wang, Y.; Li, H. Black rice addition prompted the beer quality by the extrusion as pretreatment. Food Sci. Nutr. 2019, 7, 3664-3674. [CrossRef] [PubMed]

13. Evera, E.; Abedin Abdallah, S.H.; Shuang, Z.; Sainan, W.; Yu, H. Shelf life and nutritional quality of sorghum beer: Potentials of phytogenic-based extracts. J. Agric. Food. Technol. 2019, 9, 1-14.

14. Chaves-López, C.; Rossi, C.; Maggio, F.; Paparella, A.; Serio, A. Changes occurring in spontaneous maize fermentation: An overview. Fermentation 2020, 6, 36. [CrossRef]

15. Rocha dos Santos Mathias, T.; Moreira Menezes, L.; Camporese Sérvulo, E.F. Effect of maize as adjunct and the mashing proteolytic step on the brewer wort composition. Beverages 2019, 5, 65. [CrossRef]

16. Bogdan, P.; Kordialik-Bogacka, E. Alternatives to malt in brewing. Trends Food Sci. Technol. 2017, 65, 1-9. [CrossRef]

17. Hernández-Becerra, E.; Contreras-Jiménez, B.; Vuelvas-Solorzano, A.; Millan-Malo, B.; Muñoz-Torres, C.; Oseguera-Toledo, M.E.; Rodriguez-Garcia, M.E. Physicochemical and morphological changes in corn grains and starch during the malting for Palomero and Puma varieties. Cereal Chem. 2020, 97, 404-415. [CrossRef]

18. Dabija, A. Biotehnologies in the Food Industries; Performantica Press: Iasi, Romania, 2019.

19. Puligundla, P.; Smogrovicova, D.; Mok, C.; Obulam, V.S.R. Recent developments in high gravity beer-brewing. Innov. Food Sci. Emerg. Technol. 2020, 64, 102399. [CrossRef] 
20. Goode, D.L.; Arendt, E.K. Developments in the supply of adjunct materials for brewing. In Brewing; Woodhead Publishing: Cambridge, UK, 2006; pp. 30-67.

21. Schnitzenbaumer, B.; Arendt, E.K. Brewing with up to $40 \%$ unmalted oats (Avena sativa) and sorghum (Sorghum bicolor): A review. J. Inst. Brew. 2014, 120, 315-330. [CrossRef]

22. He, Y.; Cao, Y.; Chen, S.; Ma, C.; Zhang, D.; Li, H. Analysis of flavour compounds in beer with extruded corn starch as an adjunct. J. Inst. Brew. 2018, 124, 9-15. [CrossRef]

23. Mellor, D.D.; Hanna-Khalil, B.; Carson, R. A review of the potential health benefits of low alcohol and alcohol-free beer: Effects of ingredients and craft brewing processes on potentially bioactive metabolites. Beverages 2020, 6, 25. [CrossRef]

24. Donadini, G.; Porretta, S. Uncovering patterns of consumers' interest for beer: A case study with craft beers. Food Res. Int. 2017, 91, 183-198. [CrossRef] [PubMed]

25. Morgan, D.R.; Thomas Lane, E.; Styles, D. Crafty Marketing: An Evaluation of Distinctive Criteria for "Craft" Beer. Food Rev. Int. 2020, 1-17. [CrossRef]

26. Salanță, L.C.; Coldea, T.E.; Ignat, M.V.; Pop, C.R.; Tofană, M.; Mudura, E.; Zhao, H. Non-alcoholic and craft beer production and challenges. Processes 2020, 8, 1382. [CrossRef]

27. Kerpes, R.; Fischer, S.; Becker, T. The production of gluten-free beer: Degradation of hordeins during malting and brewing and the application of modern process technology focusing on endogenous malt peptidases. Trends Food Sci. Technol. 2017, 67, 129-138. [CrossRef]

28. Ciocan, M.; Dabija, A.; Codină, G.G. Effect of some unconventional ingredients on the production of black beer. Ukr. Food J. 2020, 9, 322-331. [CrossRef]

29. Gumienna, M.; Górna, B. Gluten hypersensitivities and their impact on the production of gluten-free beer. Eur. Food Res. Technol. 2020, 247, 2147-2160. [CrossRef]

30. Adiamo, O.Q.; Fawale, O.S.; Olawoye, B. Recent trends in the formulation of gluten-free sorghum products. J. Culin. Sci. Technol. 2018, 16, 311-325. [CrossRef]

31. Dlamini, B.C.; Taylor, J.R.N.; Buys, E.M. Influence of ammonia and lysine supplementation on yeast growth and fermentation with respect to gluten-free type brewing using unmalted sorghum grain. Int. J. Food Sci. Technol. 2020, 55, 841-850. [CrossRef]

32. Yorke, J.; Cook, D.; Ford, R. Brewing with Unmalted Cereal Adjuncts: Sensory and Analytical Impacts on Beer Quality. Beverages 2021, 7, 4. [CrossRef]

33. Ambra, R.; Pastore, G.; Lucchetti, S. The Role of Bioactive Phenolic Compounds on the Impact of Beer on Health. Molecules 2021, 26, 486. [CrossRef] [PubMed]

34. Adiaha, M.S.; Agba, O.A.; Attoe, E.E.; Ojikpong, T.O.; Kekong, M.A.; Obio, A.; Undie, U.L. Effect of maize (Zea mays L.) on human development and the future of man-maize survival: A review. World Sci. News 2016, 59, 52-62.

35. Steiner, E.; Auer, A.; Becker, T.; Gastl, M. Comparison of beer quality attributes between beers brewed with $100 \%$ barley malt and 100\% barley raw material. J. Sci. Food Agric. 2012, 92, 803-813. [CrossRef] [PubMed]

36. Szambelan, K.; Nowak, J.; Szwengiel, A.; Jeleń, H. Comparison of sorghum and maize raw distillates: Factors affecting ethanol efficiency and volatile by-product profile. J. Cereal Sci. 2020, 91, 102863. [CrossRef]

37. Bussmann, R.W.; Batsatsashvili, K.; Kikvidze, Z.; Ghorbani, A.; Paniagua-Zambrana, N.Y.; Khutsishvili, M.; Tchelidze, D. Ethnobotany of Mountain Regions: Far Eastern Europe. Ethnobot. Mt. Reg. Far East. Eur. Ural North. Cauc. Turk. Iran 2020, 3-43. [CrossRef]

38. Malhotra, S.K. Diversification in Utilization of Maize and Production. Dep. Agric. Co-Oper. Farmers Welf. Minist. Agric. Farmers Welf. Gov. India A Compend. 2017, 5, 49-57.

39. Singh, N.; Singh, S.; Shevkani, K. Maize: Composition, bioactive constituents, and unleavened bread. In Flour and Breads and Their Fortification in Health and Disease Prevention; Academic Press: London, UK, 2019; pp. 111-121.

40. Shah, T.R.; Prasad, K.; Kumar, P. Maize-A potential source of human nutrition and health: A review. Cogent Food Agric. 2016, 2, 1166995 .

41. Eshetie, T. Review of quality protein maize as food and feed: In alleviating protein deficiency in developing countries. Am. J. Food Nutr. 2017, 99-105. [CrossRef]

42. Abah, C.R.; Ishiwu, C.N.; Obiegbuna, J.E.; Oladejo, A.A. Sorghum Grains: Nutritional Composition, Functional Properties and Its Food Applications. Eur. J. Nutr. Food Saf. 2020, 5, 101-111. [CrossRef]

43. Adebo, O.A. African sorghum-based fermented foods: Past, current and future prospects. Nutrients 2020, 12, 1111. [CrossRef]

44. FAOSTAT Food and Agriculture Organization Statistics. Available online: http://www.fao.org/faostat/en/\#data/QC (accessed on 25 February 2021).

45. Nnamchi, C.I.; Okolo, B.N.; Moneke, A.N. Grain and malt quality properties of some improved Nigerian sorghum varieties. J. Inst. Brew. 2014, 120, 353-359. [CrossRef]

46. Xiong, Y.; Zhang, P.; Warner, R.D.; Fang, Z. Sorghum grain: From genotype, nutrition, and phenolic profile to its health benefits and food applications. Compr. Rev. Food Sci. Food Saf. 2019, 18, 2025-2046. [CrossRef] [PubMed]

47. Perreta, M.; Ramos, J.; Tivano, J.C.; Vegetti, A. Descriptive characters of growth form in Poaceae-An overview. Flora 2011, 206, 283-293. [CrossRef]

48. Gupta, M.; Abu-Ghannam, N.; Gallaghar, E. Barley for Brewing: Characteristic Changes during Malting, Brewing and Applications of its By-Products. Compr. Rev. Food Sci. Food Saf. 2010, 9, 318-328. [CrossRef] [PubMed] 
49. Watson, S.A. Description, development, structure, and composition of the corn kernel. In Corn: Chemistry and Technology, 2nd ed.; White, P.J., Johnson, L.A., Eds.; American Association of Cereal Chemists, Inc.: St. Paul, MN, USA, 2003; pp. 69-106.

50. Dicko, M.H.; Gruppen, H.; Traoré, A.S.; Voragen, A.G.; Van Berkel, W.J. Sorghum grain as human food in Africa: Relevance of content of starch and amylase activities. Afr. J. Biotechnol. 2006, 5, 384-395.

51. Fox, G.P. Chemical composition in barley grains and malt quality. In Genetics and Improvement of Barley Malt Quality; Zhang, G., Li, C., Eds.; Springer: Berlin/Heidelberg, Germany, 2010; pp. 64-99.

52. Baik, B.K.; Ullrich, S.E. Barley for food: Characteristics, improvement, and renewed interest. J. Cereal Sci. 2008, 48, $233-242$. [CrossRef]

53. Šterna, V.; Zute, S.; Jākobsone, I. Grain composition and functional ingredients of barley varieties created in Latvia. In Proceedings of the Latvian Academy of Sciences. Section B. Natural, Exact, and Applied Sciences; Sciendo, 2015; Volume 69, pp. 158-162.

54. Le, T.A.T. Maize Malt Supplementation of Barley for the New Beer Production. Ph.D. Thesis, School of Biotechnology, Institute of Agricultural Technology, Suranaree University of Technology, Nakhon Ratchasima, Thailand, 2017.

55. Fišteš, A.; Došenovic, T.; Rakic, D.; Pajin, B.; Šereš, Z.; Simovic, Š.; Loncarevic, I. Statistical analysis of the basic chemical composition of whole grain flour of different cereal grains. Acta Univ. Sapientiae Aliment. 2014, 7, 45-53.

56. Alijošius, S.; Švirmickas, G.J.; Kliševičiūtè, V.; Gružauskas, R.; Šašytè, V.; Racevičiūtè-Stupelienè, A.; Dailidavičienè, J. The chemical composition of different barley varieties grown in Lithuania. Vet. Zootech. 2016, 73, 9-13.

57. Andersson, A.A.; Elfverson, C.; Andersson, R.; Regnér, S.; Åman, P. Chemical and physical characteristics of different barley samples. J. Sci. Food Agric. 1999, 79, 979-986. [CrossRef]

58. Ndife, J.; Nwokedi, C.U.; Ugwuona, F.U. Optimization of malting and saccharification in the production of malt beverage from maize. Niger. J. Agric. Food Environ. 2019, 15, 134-141.

59. Ignjatovic-Micic, D.; Vancetovic, J.; Trbovic, D.; Dumanovic, Z.; Kostadinovic, M.; Bozinovic, S. Grain nutrient composition of maize (Zea mays L.) drought-tolerant populations. J. Agric. Food Chem. 2015, 63, 1251-1260. [CrossRef]

60. Available online: http:/ / www.fao.org/3/T0395E/T0395E03.htm (accessed on 1 March 2021).

61. Udachan, I.S.; Sahu, A.K.; Hend, F.M. Extraction and characterization of sorghum (Sorghum bicolor L. Moench) starch. Int. Food Res. J. 2012, 19, 315-319.

62. Singh, E.; Jain, P.K.; Sharma, S. Effect of different household processing on nutritional and anti-nutritional factors in Vigna aconitifolia and Sorghum bicolour (L.) Moench seeds and their product development. J. Med. Nutr. Nutraceut. 2015, 4, 95.

63. Mohapatra, D.; Patel, A.S.; Kar, A.; Deshpande, S.S.; Tripathi, M.K. Effect of different processing conditions on proximate composition, anti-oxidants, anti-nutrients and amino acid profile of grain sorghum. Food Chem. 2019, 271, 129-135. [CrossRef]

64. Nghiem, N.P.; Montanti, J.; Johnston, D.B. Sorghum as a renewable feedstock for production of fuels and industrial chemicals. Bioengineering 2016, 3, 75-91. [CrossRef]

65. Vilela, J.D.A.S.; de Figueiredo Vilela, L.; Ramos, C.L.; Schwan, R.F. Physiological and genetic characterization of indigenous Saccharomyces cerevisiae for potential use in productions of fermented maize-based-beverages. Braz. J. Microbiol. 2020, 51, 1297-1307. [CrossRef]

66. Piacentini, K.C.; Rocha, L.O.; Savi, G.D.; Carnielli-Queiroz, L.; Corrêa, B. Beer industry in Brazil: Economic aspects, characteristics of the raw material and concerns. Kvas. Prum. 2018, 64, 284-286. [CrossRef]

67. Estevão, S.T.; e Silva, J.B.D.A.; Lourenço, F.R. Development and optimization of beer containing malted and non-malted substitutes using quality by design (QbD) approach. J. Food Eng. 2021, 289, 110182. [CrossRef]

68. Zhu, L.; Ma, T.; Mei, Y.; Li, Q. Enhancing the hydrolysis of corn starch using optimal amylases in a high-adjunct-ratio malt mashing process. Food Sci. Biotechnol. 2017, 26, 1227-1233. [CrossRef] [PubMed]

69. Poreda, A.; Czarnik, A.; Zdaniewicz, M.; Jakubowski, M.; Antkiewicz, P. Corn grist adjunct-application and influence on the brewing process and beer quality. J. Inst. Brew. 2014, 120,77-81. [CrossRef]

70. Diakabana, P.; Mvoula-Tsiéri, M.; Dhellot, J.; Kobawila, S.C.; Louembé, D. Physico-chemical characterization of brew during the brewing corn malt in the production of maize beer in Congo. Adv. J. Food Sci. Technol. 2013, 5, 671-677. [CrossRef]

71. Fumi, M.D.; Galli, R.; Lambri, M.; Donadini, G.; De Faveri, D.M. Effect of full-scale brewing process on polyphenols in Italian allzmalt and maize adjunct lager beers. J. Food Compos. Anal. 2011, 4-5, 568-573. [CrossRef]

72. Fumi, M.D.; Galli, R.; Lambri, M.; Donadini, G.; Faveri, D.M.D. Impact of full-scale brewing processes on lager beer nitrogen compounds. Eur. Food Res. Technol. 2009, 230, 209-216. [CrossRef]

73. Perez-Carrillo, E.; Serna-Saldivar, S.O.; Chuck-Hernandez, C.; Cortes-Callejas, M.L. Addition of protease during starch liquefaction affects free amino nitrogen, fusel alcohols and ethanol production of fermented maize and whole and decorticated sorghum mashes. Biochem. Eng. J. 2012, 67, 1-9. [CrossRef]

74. Zweytik, G.; Berghofer, E. Production of gluten-free beer. In Gluten-Free Food Science and Technology; Gallagher, E., Ed.; WileyBlackwell: Oxford, UK, 2009.

75. Romero-Medina, A.; Estarrón-Espinosa, M.; Verde-Calvo, J.R.; Lelièvre-Desmas, M.; Escalona-Buendía, H.B. Renewing traditions: A sensory and chemical characterisation of mexican pigmented corn beers. Foods 2020, 9, 886. [CrossRef]

76. Bernal-Gil, N.Y.; Favila-Cisneros, H.J.; Zaragoza-Alonso, J.; Cuffia, F.; Rojas-Rivas, E. Using projective techniques and Food Neophobia Scale to explore the perception of traditional ethnic foods in Central Mexico: A preliminary study on the beverage Sende. J. Sens. Stud. 2020, 35, e12606. [CrossRef] 
77. Bassi, D.; Orrù, L.; Cabanillas Vasquez, J.; Cocconcelli, P.S.; Fontana, C. Peruvian chicha: A focus on the microbial populations of this ancient Maize-based fermented beverage. Microorganisms 2020, 8, 93. [CrossRef]

78. Williams, P.R.; Nash, D.J.; Henkin, J.M.; Armitage, R.A. Archaeometric Approaches to Defining Sustainable Governance: Wari Brewing Traditions and the Building of Political Relationships in Ancient Peru. Sustainability 2019, 11, 2333. [CrossRef]

79. Adekoya, I.; Obadina, A.; Adaku, C.C.; De Boevre, M.; Okoth, S.; De Saeger, S.; Njobeh, P. Mycobiota and co-occurrence of mycotoxins in South African maize-based opaque beer. Int. J. Food Microbiol. 2018, 270, 22-30. [CrossRef] [PubMed]

80. Hlangwani, E.; Adebiyi, J.A.; Doorsamy, W.; Adebo, O.A. Processing, Characteristics and Composition of Umqombothi (a South African Traditional Beer). Processes 2020, 8, 1451. [CrossRef]

81. Cason, E.D.; Mahlomaholo, B.J.; Taole, M.M.; Abong, G.O.; Vermeulen, J.G.; De Smidt, O.; Viljoen, B. Bacterial and fungal dynamics during the fermentation process of sesotho, a traditional beer of Southern Africa. Front. Microbiol. 2020, $11,1451$. [CrossRef]

82. Gadaga, T.H.; Lehohla, M.; Ntuli, V. Traditional fermented foods of Lesotho. J. Microbiol. Biotechnol. Food Sci. 2020, 9, $2387-2391$.

83. Mawonike, R.; Chigunyeni, B.; Chipumuro, M. Process improvement of opaque beer (chibuku) based on multivariate cumulative sum control chart. J. Inst. Brew. 2018, 124, 16-22. [CrossRef]

84. Konfo, C.T.R.; Chabi, N.W.; Dahouenon-Ahoussi, E.; Cakpo-Chichi, M.; Soumanou, M.M.; Sohounhloue, D.C.K. Improvement of African traditional sorghum beers quality and potential applications of plants extracts for their stabilization: A review. $J$. Microbiol. Biotechnol. Food Sci. 2020, 9, 190-196. [CrossRef]

85. Andualem, B.; Gessesse, A. Isolation and identification of amylase producing yeasts in 'tella' (Ethiopian local beer) and their amylase contribution for 'tella' production. J. Microbiol. Biotechnol. Food Sci. 2020, 9, 30-34.

86. Fentie, E.G.; Emire, S.A.; Demsash, H.D.; Dadi, D.W.; Shin, J.-H. Cereal- and Fruit-Based Ethiopian Traditional Fermented Alcoholic Beverages. Foods 2020, 9, 1781. [CrossRef] [PubMed]

87. Adesulu-Dahunsi, A.T.; Dahunsi, S.O.; Olayanju, A. Synergistic microbial interactions between lactic acid bacteria and yeasts during production of Nigerian indigenous fermented foods and beverages. Food Control 2020, 110, 106963. [CrossRef]

88. Krstanović, V.; Habschied, K.; Lukinac, J.; Jukić, M.; Mastanjević, K. The Influence of Partial Substitution of Malt with Unmalted Wheat in Grist on Quality Parameters of Lager Beer. Beverages 2020, 6, 7. [CrossRef]

89. Obatolu, V.A.; Adeniyi, P.O.; Ashaye, O.A. Nutritional, Sensory and Storage Quality of Sekete from Zea mays. Int. J. Food Sci. Nutr. 2016, 6, 73-80.

90. Agu, R.C.A. comparison of maize, sorghum and barley as brewing adjuncts. J. Inst. Brew. 2002, 108, 19-22. [CrossRef]

91. Goode, D.L.; Arendt, E.K. Pilot Scale Production of a Lager Beer from a Grist Containing 50\% Unmalted Sorghum. J. Inst. Brew. 2003, 109, 208-217. [CrossRef]

92. Ogbonna, A.C. Current Developments in Malting and Brewing Trials with Sorghum in Nigeria: A Review. J. Inst. Brew. 2011, 117, 394-400. [CrossRef]

93. Beta, T.; Rooney, L.W.; Waniska, R.D. Malting characteristics of sorghum cultivars. Cereal 1995, 72, 533-538.

94. Chandra, G.S.; Proudlove, M.O.; Baxter, E.D. The structure of barley endosperm an important determinant of malt modification. J. Sci. Food Agric. 1999, 79, 37-46. [CrossRef]

95. Oyewole, O.I.; Agboola, F.K. Comparative studies on properties of amylases extracted from kilned and unkilned malted sorghum and corn. Int. J. Biotechnol. Mol. Biol. Res. 2011, 2, 146-149.

96. Eneje, L.O.; Ogu, E.O.; Aloh, C.U.; Agu, R.C.; Palmer, G.H. Effects of steeping and germination on malting performance of Nigerian white and yellow maize varieties. Process. Biochem. 2004, 39, 1013-1016. [CrossRef]

97. Taylor, J.R.N.; Dlamini, B.C.; Kruger, J. 125th anniversary review: The science of the tropical cereals sorghum, maize and rice in relation to lager beer brewing. J. Inst. Brew. 2013, 119, 1-14. [CrossRef]

98. Espinosa-Ramírez, J.; Pérez-Carrillo, E.; Serna-Saldívar, S.O. Production of brewing worts from different types of sorghum malts and adjuncts supplemented with $\beta$-amylase or amyloglucosidase. J. Am. Soc. Brew. Chem. 2013, 71, 49-56. [CrossRef]

99. Heredia-Olea, E.; Cortés-Ceballos, E.; Serna-Saldívar, S.O. Malting sorghum with Aspergillus oryzae enhances gluten-free wort yield and extract. J. Am. Soc. Brew. Chem. 2017, 75, 116-121. [CrossRef]

100. Espinosa-Ramírez, J.; Pérez-Carrillo, E.; Serna-Saldívar, S.O. Maltose and glucose utilization during fermentation of barley and sorghum lager beers as affected by $\beta$-amylase or amyloglucosidase addition. J. Cereal Sci. 2014, 60, 602-609. [CrossRef]

101. Urias-Lugo, D.A.; Saldivar, S.O.S. Effect of amyloglucosidase on properties of lager beers produced from sorghum malt and waxy grits. J. Am. Soc. Brew. Chem. 2005, 63, 63-68. [CrossRef]

102. Shen, S.; Huang, R.; Li, C.; Wu, W.; Chen, H.; Shi, J.; Chen, S.; Ye, X. Phenolic Compositions and Antioxidant Activities Differ Significantly among Sorghum Grains with Different Applications. Molecules 2018, 23, 1203. [CrossRef]

103. Attchelouwa, C.K.; Aka-Gbézo, S.; N'guessan, F.K.; Kouakou, C.A.; Djè, M.K. Biochemical and Microbiological Changes during the Ivorian Sorghum Beer Deterioration at Different Storage Temperatures. Beverages 2017, 3, 43. [CrossRef]

104. Embashu, W.; Iileka, O.; Nantanga, K.K.M. Namibian opaque beer: A review. J. Inst. Brew. 2019, 125, 4-9. [CrossRef]

105. Zaukuu, J.L.Z.; Oduro, I.; Ellis, W.O. Processing methods and microbial assessment of pito (an African indigenous beer), at selected production sites in Ghana. J. Inst. Brew. 2016, 122, 736-744. [CrossRef]

106. Ogbonna, A.C. Developments in the malting and brewing trials with sorghum. World J. Microbiol. Biotechnol. 1992, 8, 87-91. [CrossRef] [PubMed]

107. Agu, R.C.; Palmer, G.H. A reassessment of sorghum for lager-beer brewing. Bioresour. Technol. 1998, 66, 253-261. [CrossRef] 
108. Owuama, C.I. Brewing beer with sorghum. J. Inst. Brew. 1999, 105, 23-34. [CrossRef]

109. Rubio-Flores, M.; García-Arellano, A.R.; Perez-Carrillo, E.; Serna-Saldivar, S.O. Use of Aspergillus oryzae during sorghum malting to enhance yield and quality of gluten-free lager beers. Bioresour. Bioprocess. 2020, 7, 1-11. [CrossRef]

110. Sawadogo-Lingani, H.; Lei, V.; Diawara, B.; Nielsen, D.; Møller, P.; Traoré, A.; Jakobsen, M. The biodiversity of predominant lactic acid bacteria in dolo and pito wort for the production of sorghum beer. J. Appl. Microbiol. 2007, 103, 765-777. [CrossRef]

111. Djameh, C.; Saalia, F.K.; Sinayobye, E.; Budu, A.; Essilfie, G.; Mensah-Brown, H.; Sefa-Dedeh, S. Optimization of the sorghum malting process for pito production in Ghana. J. Inst. Brew. 2015, 121, 106-112. [CrossRef]

112. Adadi, P.; Kanwugu, O.N. Potential application of tetrapleura tetraptera and hibiscus sabdariffa (malvaceae) in designing highly flavoured and bioactive pito with functional properties. Beverages 2020, 6, 22. [CrossRef]

113. Djameh, C.; Ellis, W.O.; Oduro, I.; Saalia, F.K.; Haslbeck, K.; Komlaga, G.A. West African sorghum beer fermented with Lactobacillus delbrueckii and Saccharomyces cerevisiae: Fermentation by-products. J. Inst. Brew. 2019, 125, 326-332. [CrossRef]

114. Vázquez-Araújo, L.; Chambers IV, E.; Cherdchu, P. Consumer Input for Developing Human Food Products Made with Sorghum Grain. J. Food Sci. 2012, 77, S384-S389. [CrossRef]

115. N'Guessan, F.K.; Coulibaly, H.W.; Alloue-Boraud, M.W.A.; Cot, M.; Djè, K.M. Production of freeze-dried yeast culture for the brewing of traditional sorghum beer, tchapalo. Food Sci. Nutr. 2016, 4, 34-41. [CrossRef]

116. Ezekiel, C.N.; Ayeni, K.I.; Misihairabgwi, J.M.; Somorin, Y.M.; Chibuzor-Onyema, I.E.; Oyedele, O.A.; Abia, W.A.; Sulyok, M.; Shephard, G.S.; Krska, R. Traditionally Processed Beverages in Africa: A Review of the Mycotoxin Occurrence Patterns and Exposure Assessment. Compr. Rev. Food Sci. Food Saf. 2018, 17, 334-351. [CrossRef]

117. Aka, S.; Dridi, B.; Bolotin, A.; Yapo, E.A.; Koussemon-Camara, M.; Bonfoh, B.; Renault, P. Characterization of lactic acid bacteria isolated from a traditional Ivoirian beer process to develop starter cultures for safe sorghum-based beverages. Int. J. Food Microbiol. 2020, 322, 108547. [CrossRef] [PubMed]

118. Tano, M.B.; Aka-Gbezo, S.; Attchelouwa, C.K.; Koussémon, M. Use of Lactic Acid Bacteria as Starter Cultures in the Production of Tchapalo, a Traditional Sorghum Beer from Côte d'Ivoire. Am. J. Food Sci. Health 2020, 6, $23-31$.

119. Shimotsu, S.; Asano, S.; Iijima, K.; Suzuki, K.; Yamagishi, H.; Aizawa, M. Investigation of beer-spoilage ability of Dekkera/Brettanomyces yeasts and development of multiplex PCR method for beer-spoilage yeasts. J. Inst. Brew. 2015, 121, 177-180. [CrossRef]

120. Rogerson, C.M. African traditional beer: Changing organization and spaces of South Africa's sorghum beer industry. Afr. Geogr. Rev. 2019, 38, 253-267. [CrossRef]

121. Aruna, C.; VisaradaI, K.B.R.S. Sorghum grain in food and brewing industry. In Breeding Sorghum for Diverse End Uses; Woodhead Publishing: Cambridge, UK, 2019; pp. 209-228.

122. Tamang, J.P.; Cotter, P.; Endo, A. Fermented foods in a global age: East meets West. Compr. Rev. Food Sci. Food Saf. 2020, 19, 184-217. [CrossRef] [PubMed]

123. Pale, S.; Taonda, S.J.; Bougouma, B.; Mason, S.C. Sorghum malt and traditional beer (dolo) quality assessment in Burkina Faso. Ecol. Food Nutr. 2010, 49, 129-141. [CrossRef]

124. Hadebe, S.T.; Modi, A.T.; Mabhaudhi, T. Drought Tolerance and Water Use of Cereal Crops: A Focus on Sorghum as a Food Security Crop in Sub-Saharan Africa. J. Agron. Crop. Sci. 2017, 203, 177-191. [CrossRef]

125. Mogmenga, I.; Dadiré, Y.; Somda, M.K.; Keita, I.; Ezeogu, L.I.; Ugwuanyi, J.; Traoré, A.S. Isolation and Identification of Indigenous Yeasts from "Rabilé", a Starter Culture Used for Production of Traditional Beer "dolo", a Condiment in Burkina Faso. Adv. Microbiol. 2019, 9, 646. [CrossRef]

126. Disharoon, A.; Boyles, R.; Jordan, K.; Kresovich, S. Exploring diverse sorghum (Sorghum bicolor (L.) Moench) accessions for malt amylase activity. J. Inst. Brew. 2021, 127, 5-12. [CrossRef]

127. Nso, E.; Ajebesome, P.; Mbofung, C.; Palmer, G. Properties of Three Sorghum Cultivars Used for the Production of Bili-Bili Beverage in Northern Cameroon. J. Inst. Brew. 2003, 109, 245-250. [CrossRef]

128. Maoura, N.; Mbaiguinam, M.; Nguyen, H.V.; Gaillardin, C.; Pourquie, J. Identification and typing of the yeast strains isolated from bili bili, a traditional sorghum beer of Chad. Afr. J. Biotechnol. 2005, 4, 646-656.

129. Desobgo, Z.S.C.; Nso, E.J.; Tenin, D.; Kayem, G.J. Modelling and Optimizing of Mashing Enzymes—Effect on Yield of Filtrate of Unmalted Sorghum by Use of Response Surface Methodology. J. Inst. Brew. 2010, 116, 62-69. [CrossRef]

130. Kubo, R.; Funakawa, S.; Araki, S.; Kitabatake, N. Production of indigenous alcoholic beverages in a rural village of Cameroon. J. Inst. Brew. 2014, 120, 133-141. [CrossRef]

131. Embashu, W.; Nantanga, K.K.M. Malts: Quality and phenolic content of pearl millet and sorghum varieties for brewing nonalcoholic beverages and opaque beers. Cereal Chem. 2019, 96, 765-774. [CrossRef]

132. Soji, P.A. The Potential Importance of Maize, (Zea mays L), in Nigeria, [A Case Study of 2800 Farmers Sampled at Different Locations]. Adv. Biochem. 2020, 8, 1. [CrossRef]

133. Palanisamy, C.P.; Cui, B.; Zhang, H.; Jayaraman, S.; Kodiveri Muthukaliannan, G. A Comprehensive Review on Corn Starch-Based Nanomaterials: Properties, Simulations, and Applications. Polymers 2020, 12, 2161. [CrossRef] [PubMed]

134. Gálvez Ranilla, L. The Application of Metabolomics for the Study of Cereal Corn (Zea mays L.). Metabolites 2020, 10, 300. [CrossRef] [PubMed]

135. Green, D.I.G.; Agu, R.C.; Bringhurst, T.A.; Brosnan, J.M.; Jack, F.R.; Walker, G.M. Maximizing alcohol yields from wheat and maize and their co-products for distilling or bioethanol production. J. Inst. Brew. 2015, 121, 332-337. [CrossRef] 
136. Onuki, S.; Koziel, J.A.; Jenks, W.S.; Cai, L.; Grewell, D.; van Leeuwen, J.H. Taking ethanol quality beyond fuel grade: A review. J. Inst. Brew. 2016, 122, 588-598. [CrossRef]

137. Ai, Y.; Jane, J. Macronutrients in Corn and Human Nutrition. Compr. Rev. Food Sci. Food Saf. 2016, 15, 581-598. [CrossRef]

138. Ortíz-Islas, S.; García-Lara, S.; Preciado-Ortíz, R.E.; Serna-Saldívar, S.O. Fatty acid composition and proximate analysis of improved high-oil corn double haploid hybrids adapted to subtropical areas. Cereal Chem. 2019, 96, 182-192. [CrossRef]

139. Shi, M.; Gao, Q.; Liu, Y. Corn, potato, and wrinkled pea starches with heat-moisture treatment: Structure and digestibility. Cereal Chem. 2018, 95, 603-614. [CrossRef]

140. Zhang, Y.; Li, Y. Comparison of physicochemical and mechanical properties of edible films made from navy bean and corn starches. J. Sci. Food Agric. 2021, 101, 1538-1545. [CrossRef]

141. Ari Akin, P.; Miller, R.; Jaffe, T.; Koppel, K.; Ehmke, L. Sensory profile and quality of chemically leavened gluten-free sorghum bread containing different starches and hydrocolloids. J. Sci. Food Agric. 2019, 99, 4391-4396. [CrossRef] [PubMed]

142. Galassi, E.; Taddei, F.; Ciccoritti, R.; Nocente, F.; Gazza, L. Biochemical and technological characterization of two C4 gluten-free cereals: Sorghum bicolor and Eragrostis tef. Cereal Chem. 2020, 97, 65-73. [CrossRef]

143. Awobusuyi, T.D.; Pillay, K.; Siwela, M. Consumer Acceptance of Biscuits Supplemented with a Sorghum-Insect Meal. Nutrients 2020, 12, 895. [CrossRef] [PubMed]

144. Dabija, A. Unconventional Raw Materials for the Bakery Industry; Performantica Publishing House: Iași, Romania, 2020; ISBN 978-606-685-731-4.

145. Rashwan, A.K.; Yones, H.A.; Karim, N.; Taha, E.M.; Chen, W. Potential processing technologies for developing sorghum-based food products: An update and comprehensive review. Trends Food Sci. Technol. 2021, 110, 168-182. [CrossRef]

146. Available online: https://www.mordorintelligence.com/industry-reports/beer-market (accessed on 25 March 2021). 